\title{
Discharge, Suspended Sediment, and Salinity in the Gulf Intracoastal Waterway and Adjacent Surface Waters in South-Central Louisiana, 1997-2008
}

Scientific Investigations Report 2015-5132 
Cover, Gulf Intracoastal Waterway near Bay Wallace east of Morgan City. 


\section{Discharge, Suspended Sediment, and Salinity in the Gulf Intracoastal Waterway and Adjacent Surface Waters in South- Central Louisiana, 1997-2008}

By Christopher M. Swarzenski and Scott M. Perrien

Scientific Investigations Report 2015-5132 


\title{
U.S. Department of the Interior SALLY JEWELL, Secretary
}

\section{U.S. Geological Survey \\ Suzette M. Kimball, Acting Director}

\author{
U.S. Geological Survey, Reston, Virginia: 2015
}

For more information on the USGS - the Federal source for science about the Earth, its natural and living resources, natural hazards, and the environment—visit http://www.usgs.gov or call 1-888-ASK-USGS.

For an overview of USGS information products, including maps, imagery, and publications, visit http://www.usgs.gov/pubprod/.

Any use of trade, firm, or product names is for descriptive purposes only and does not imply endorsement by the U.S. Government.

Although this information product, for the most part, is in the public domain, it also may contain copyrighted materials as noted in the text. Permission to reproduce copyrighted items must be secured from the copyright owner.

Suggested citation:

Swarzenski, C.M., and Perrien, S.M., 2015, Discharge, suspended sediment, and salinity in the Gulf Intracoastal Waterway and adjacent surface waters in south-central Louisiana, 1997-2008: U.S. Geological Survey Scientific Investigations Report 2015-5132, 21 p., http://dx.doi.org/10.3133/sir20155132.

ISSN 2328-031X (print)

ISSN 2328-0328 (online 


\section{Contents}

Abstract
Introduction
Purpose and Scope
Description of Study Area
Discharge, Suspended Sediment, and Salinity
$\quad$ Sischarge
Interannual Variability
Implications for Coastal Louisiana
Summary
References Cited

\section{Figures}

1. Map showing surface-water data collection sites in the Gulf Intracoastal Waterway and adjacent water bodies in south-central Louisiana

2. Graph showing monthly average stage of the Lower Atchafalaya River at Morgan City, Louisiana (average [1997-2008]; sustained high water [1993]; low water [2000, 2006]; and peak flood [2008])

3. Graph showing relation between monthly average discharge in the Gulf Intracoastal Waterway (GIWW) at Bayou Sale Ridge near Franklin and monthly average discharge of the Wax Lake Outlet at Calumet

4. Graphs showing relation between monthly average discharge in the Gulf Intracoastal Waterway (GIWW) near Bay Wallace east of Morgan City and monthly average discharge of the Lower Atchafalaya River at Morgan City or Bayou Boeuf at Railroad Bridge near Amelia (panels A and B); graphs showing relation between monthly average discharge in the GIWW at Houma or west of Bayou Lafourche at Larose and monthly average discharge of the GIWW near Bay Wallace east of Morgan City (panels C and D). Correlation in panel B is only for a Lower Atchafalaya River stage of 3 feet or less North American Vertical Datum of 1988 (NAVD 88)

5. Graph showing percent time the Lower Atchafalaya River at Morgan City exceeded indicated stage. Stage was averaged in 10 -year increments starting in January 1940 and extending through December 2008

6. Graphs showing comparison of instantaneous discharge measurements made in 1997 and 1998 and measurements made in 2007 and 2008 in relation to stage of the Lower Atchafalaya River at Morgan City

7. Boxplots showing statistical summary of suspended-sediment concentrations collected between 1997 and 2008 at selected locations in the Gulf Intracoastal Waterway (GIWW) and adjacent surface-water bodies. Site numbers in parentheses. 
8. Graphs showing monthly average salinity at selected stations in south-central Louisiana under average, sustained high water, low water, and peak flood conditions of the Atchafalaya River. Not all stations were operational in 1993; months with more than 50 percent missing data are not shown

9. Graphs showing monthly average salinity in parts per thousand at selected stations in Barataria Basin under average and low water conditions of the Atchafalaya River. The Davis Pond Freshwater Diversion Structure was not operational in 2000

\section{Tables}

1. Data-collection sites and types of data collected along the Gulf Intracoastal Waterway and adjacent surface-water bodies in south-central Louisiana, 1997-2008

2. Monthly average discharge of the Atchafalaya River at Simmesport, Louisiana, and monthly average precipitation at Morgan City, Louisiana, for indicated time periods (average [1997-2008]; sustained high water [1993]; low water [2000; 2006]; and peak flood [2008])

3. Summary of instantaneous discharge measurements at selected sites along or near the Gulf Intracoastal Waterway in south-central Louisiana, 1997-2008

4. Discharge at selected locations in the Gulf Intracoastal Waterway and adjacent waterways averaged for indicated stage increments of the Lower Atchafalaya River at Morgan City, 1997-2008

5. Estimated discharge in the Gulf Intracoastal Waterway at stations west of the Lower Atchafalaya River at Morgan City; data presented are for averages from 1997 to 2008 , for a sustained high water year (1993), for a low water year (2006), and for a peak flood year (2008)

6. Estimated discharge in the Gulf Intracoastal Waterway at stations east of the Lower Atchafalaya River at Morgan City; data presented are for averages from 1997 to 2008 , for a sustained high water year (1993), for a low water year (2006), and for a peak flood year (2008)

7. Monthly average continuous discharge at stations with continuous index velocity measurements along the Gulf Intracoastal Waterway and at the Davis Pond and Caernarvon freshwater diversions; data presented are for averages from 2003 to 2008, for a low water year (2006), and for a peak flood year (2008) 


\section{Conversion Factors}

Inch/Pound to International System of Units

\begin{tabular}{lll}
\hline \multicolumn{1}{c}{ Multiply } & \multicolumn{1}{c}{ By } & \multicolumn{1}{c}{ To obtain } \\
\hline \multicolumn{1}{c}{ Flow rate } \\
\hline cubic foot per second $\left(\mathrm{ft}^{3} / \mathrm{s}\right)$ & 0.02832 & cubic meter per second $\left(\mathrm{m}^{3} / \mathrm{s}\right)$ \\
cubic foot per second $\left(\mathrm{ft}^{3} / \mathrm{s}\right)$ & 1.9835 & acre-foot per day $(\mathrm{acre}-\mathrm{ft} / \mathrm{d})$ \\
mile $(\mathrm{mi})$ & 1.609 & kilometer $(\mathrm{km})$ \\
\hline
\end{tabular}

\section{Datum}

Vertical coordinate information is referenced to North American Vertical Datum of 1988 (NAVD 88).

\section{Supplemental Information}

Concentrations of chemical constituents in water are given in either milligrams per liter (mg/L) or micrograms per liter $(\mu \mathrm{g} / \mathrm{L})$.

\section{Abbreviations}

$\begin{array}{ll}\text { ADCP } & \text { acoustic Doppler current profiler } \\ \text { GIWW } & \text { Gulf Intracoastal Waterway } \\ \text { HNC } & \text { Houma Navigation Canal } \\ \text { LAR } & \text { Lower Atchafalaya River } \\ \text { USACE } & \text { U.S. Army Corps of Engineers } \\ \text { USGS } & \text { U.S. Geological Survey } \\ \text { WLO } & \text { Wax Lake Outlet }\end{array}$





\title{
Discharge, Suspended Sediment, and Salinity in the Gulf Intracoastal Waterway and Adjacent Surface Waters in South-Central Louisiana, 1997-2008
}

\author{
By Christopher M. Swarzenski and Scott M. Perrien
}

\section{Abstract}

Discharge, suspended sediment, and salinity data collected between 1997 and 2008 indicate that the Gulf Intracoastal Waterway (GIWW) is an important distributary of river water and suspended sediments to coastal wetlands in south-central coastal Louisiana. Following natural hydraulic gradients, the GIWW passively distributes freshwater and suspended sediments from the Atchafalaya River to areas at least 30 to 50 miles west and east, respectively, of Morgan City. The magnitude and reach of the discharge in the GIWW increase as stage of the Wax Lake Outlet at Calumet and Lower Atchafalaya River (LAR) at Morgan City increase. The magnitude and duration of discharge vary from year to year depending on the flow regime of the Atchafalaya River. Annual discharge of water in the GIWW was greater during years when stage of the LAR remained anomalously high throughout the year, compared with average and peak flood years. During years when Atchafalaya River flow is low, Bayou Boeuf, a waterway draining the Verret subbasin, becomes a major source of water maintaining the eastward flow in the GIWW. The GIWW is the only means of getting river water to some parts of coastal Louisiana.

The length of time stage of the LAR at Morgan City exceeds a given height has increased from the 1940s to 2008. This shift has increased the length of time the GIWW functions as a predictable distributary of river water each year. Similar shifts in the future could be expected to increase the duration and amounts of river water reaching coastal Louisiana wetlands through the GIWW.

Median suspended-sediment concentrations in the GIWW to the west of Morgan City were around 160 milligrams per liter (mg/L). In the GIWW east of Morgan City, median concentrations were 120-160 mg/L, except in Bayou Boeuf at Railroad Bridge in Amelia and the parts of the GIWW between Bayou Boeuf and the Houma Navigation Canal; median concentrations here were around $100 \mathrm{mg} / \mathrm{L}$.

River water penetrates much of the Louisiana coast, as demonstrated by the large year-to-year fluctuations in salinity regimes of intradistributary basins in response to differences in flow regimes of the Mississippi and the Atchafalaya Rivers. This occurs directly through inflow along the GIWW and through controlled diversions and indirectly by transport into basin interiors after mixing with the Gulf of Mexico. The GIWW plays an important role in moderating salinity in intradistributary basins; for example, salinity in surface waters just south of the GIWW between Bayou Boeuf and the Houma Navigation Canal remained low even during a year with prolonged low water (2000).

\section{Introduction}

The Gulf Intracoastal Waterway (GIWW) is a major ship channel traversing the entire Louisiana coast along the interface between wetlands and upland (fig. 1). Following natural hydraulic gradients, the GIWW captures water from the Lower Atchafalaya River (LAR) and the Wax Lake Outlet (WLO) and distributes it west and east to many parts of Louisiana's coastal wetlands (Paille, 1997; Swarzenski, 2003). Most of the water flowing in the GIWW comes from the Atchafalaya River, with additional inflow from the Charenton Drainage and Navigation Canal and Bayou Boeuf. Discharge in the Atchafalaya River is composed of about 30 percent of the combined discharge of the Red River and the Mississippi River at the Old River Control Structure. This amount is about 25 percent of the total discharge of the Mississippi River above the Old River Control Structure and auxiliary structures. On average, about 80-90 percent of the discharge in the Atchafalaya River comes from the Mississippi River (Wells and Demas, 1977).

Prior to the construction of the GIWW, the upper, lowsalinity reaches of intradistributary basins in the Mississippi River Delta were hydrologically isolated from one another; freshwater entered each basin through local streamflow, runoff, and precipitation. By cutting across natural levees of former Mississippi River distributaries in the upper reaches of these basins, the GIWW has enabled direct hydrological exchange between and among intradistributary basins of the Mississippi River Delta. This feature, along with the connecting northsouth ship channels dug to service the offshore oil industry (for example, the Houma Navigation Canal [HNC] and the Barataria Bay Waterway), represents a radical departure from natural delta plain hydrology. The north-south trending ship channels have allowed the frequent, rapid northward movement of saltwater from offshore into fresher parts of basins. These salt pulses, generated during storm surges associated with tropical 


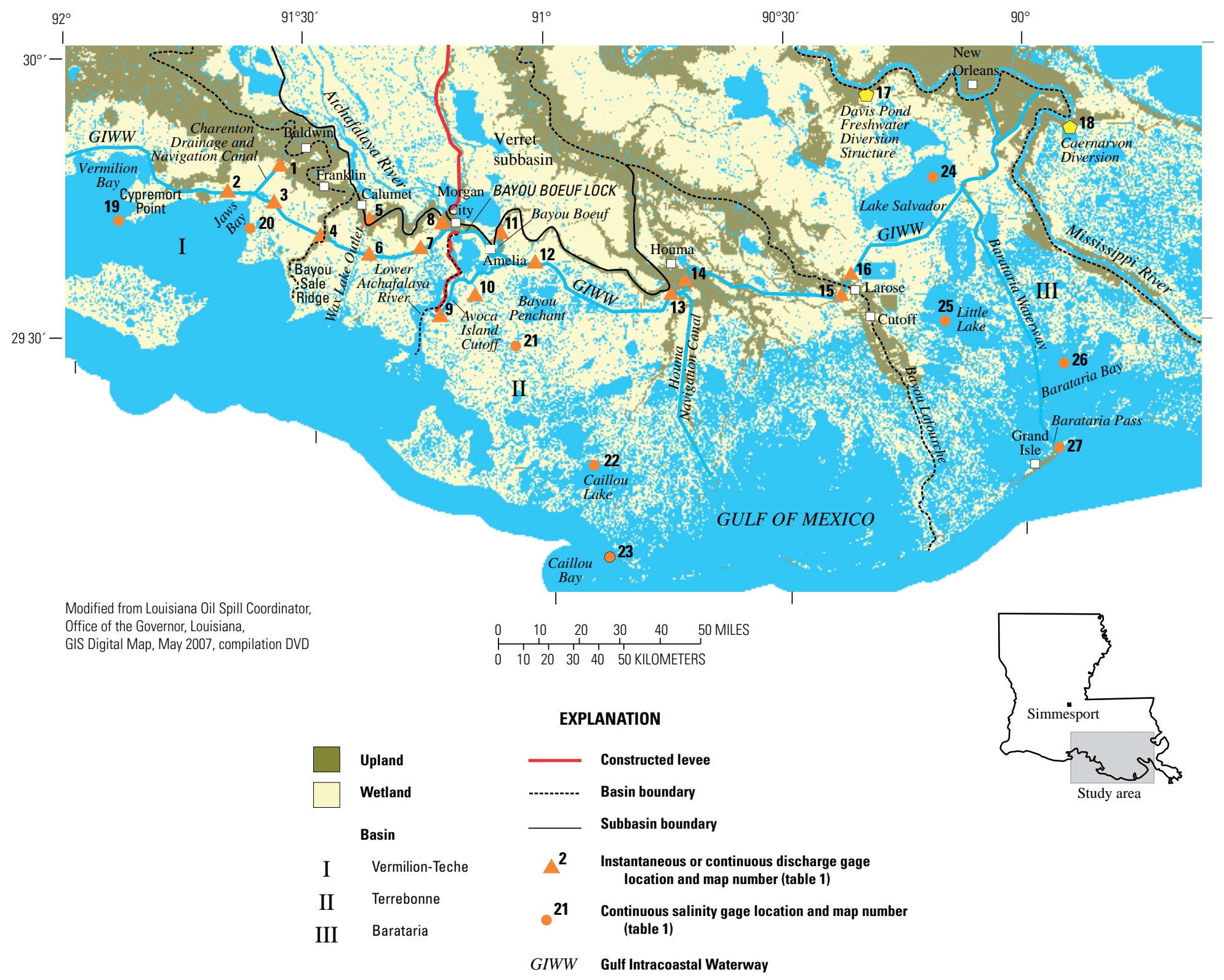

Figure 1. Surface-water data collection sites in the Gulf Intracoastal Waterway and adjacent water bodies in south-central Louisiana. 
storms and hurricanes, can then travel laterally in the GIWW (Swarzenski, 2003). In combination with the lateral distribution of fresh river water from upland runoff and the Atchafalaya River along the prevailing hydrologic gradients during the remainder of the time, the original, natural north-south estuarine salinity gradient of the intradistributary basins has been disrupted. The hydrologic alterations have had and continue to have broad implications for basic estuarine ecology and also for restoration activities in the Mississippi River Delta.

The GIWW provides an escape route for floodwaters carried through the Atchafalaya River Basin. Understanding discharge along the GIWW is helpful in evaluating flooding threats to surrounding communities. The freshwater, nutrients, and suspended sediments flowing in the GIWW are important resources that could support coastal Louisiana restoration efforts with minimal cost.

In 1997, the U.S. Geological Survey (USGS) began operating a network of stations that monitor velocity, stage, and discharge in the GIWW and several connecting ship channels. This effort was initiated in cooperation with Federal agencies concerned with flood control and environmental quality in the GIWW, principally the U.S. Army Corps of Engineers (USACE) but also including the U.S. Fish and Wildlife Service, Natural Resources Conservation Service, the U.S. Environmental Protection Agency, and the Coastal Wetlands Protection, Planning, and Restoration Act Task Force. An initial report described surface hydrology of the GIWW by using the initial 3 years of data collection from 1997 to 1999 (Swarzenski, 2003).

\section{Purpose and Scope}

The purpose of this report is to summarize the discharge and suspended sediment in the GIWW and to describe effects of the discharge on salinity in surrounding surface waters and wetlands. Mineral sediments are an important component of wetland soils, and their delivery to wetlands is essential for wetland health. This report characterizes both discharge and suspended sediment in the GIWW and selected adjacent surface waters between Cypremort Point, Louisiana, and Larose, La., from October 1997 through December 2008 and how the fresh water flowing in the GIWW affected salinity in adjacent surface waters. Instantaneous discharge and suspended-sediment data collected during synoptic surveys and discharge data computed from continuous velocity gages were used to evaluate streamflow in the GIWW in relation to varying flow conditions of the Atchafalaya River, an important source of water to the GIWW. Flow regimes evaluated for this study included average, low water, sustained high water, and peak flood years. How this variable distribution of freshwater via the GIWW affected salinity in major Louisiana coastal basins was evaluated by using continuously recording salinity stations. Quantification of the flow and the flux of suspended sediments in the GIWW and how this relates to salinity in coastal Louisiana basins could help State and Federal agencies in implementing flood-control measures and designing coastal wetland restoration projects.

\section{Description of Study Area}

The study area includes the GIWW and adjacent water bodies in south-central coastal Louisiana from Cypremort Point in the west to Bayou Lafourche in the east (fig. 1). The study area also includes the Verret subbasin to the north and east of Morgan City. The Barataria Basin, the Terrebonne Basin, and the Vermilion-Teche Basin receive various amounts of river water inflow and also are included within the study area. Houma and Morgan City are regional population centers.

West of Morgan City, the GIWW trends westward across the WLO, past Jaws Bay and Cypremort Point to southwestern Louisiana (fig. 1). East of Morgan City, the GIWW is hydraulically disconnected from the LAR by the Bayou Boeuf navigation lock and the Avoca Island levee (fig. 1). The levee was completed in the early 1950s. At the termination of the levee, about 10 miles south of Morgan City, the Avoca Island Cutoff captures water from the LAR and carries it in a northeasterly direction back towards the GIWW. Bayou Penchant, which flows easterly captures some of the water in the Avoca Island Cutoff before it intersects the GIWW. Bayou Boeuf drains the Verret subbasin, flowing into the GIWW just east of the Bayou Boeuf Lock at Morgan City. The GIWW extends eastward to Houma, crossing the HNC and Bayou Lafourche before continuing on towards New Orleans, where navigation locks separate the GIWW from the Mississippi River.

West of the WLO continuing to east of Jaws Bay, the GIWW has well-defined, higher elevation spoil banks that confine the streamflow and direct it towards Jaws Bay, a shallow bay contiguous with the Gulf of Mexico (fig. 1). To the east, the GIWW crosses forested and emergent wetlands near the upland-wetland interface between Morgan City and the HNC. Along this segment, the GIWW has poorly defined spoil banks with many breaks and openings providing substantial leakage to the interior wetlands. Easterly flow is increasingly confined towards the confluence with the HNC, and some of the leaked flow is funneled back into the GIWW before reaching the HNC.

\section{Approach and Methods}

Discrete (instantaneous) discharge measurements were used to describe flow at 12 stations on the GIWW or part of the primary conveyance system and 2 stations connected to the GIWW (fig. 1, table 1). Measurements were made during synoptic surveys, lasting from 2 to 3 days. Between 52 and 62 measurements were made at most stations. Computed hourly discharge derived from relations using instantaneous discharge and continuously recording point-velocity and stage measurements (Morlock and others, 2001) was determined for the Charenton Drainage Canal at Baldwin (site 1), Bayou Boeuf at Railroad Bridge at Amelia (site 11), Bayou Penchant south of Morgan City (site 10), and for the GIWW at Bayou Sale Ridge near Franklin (site 4), at Houma (site 14), and west of Bayou Lafourche at Larose (site 15). 
Table 1. Data-collection sites and types of data collected along the Gulf Intracoastal Waterway and adjacent surface-water bodies in south-central Louisiana, 1997-2008.

[X, parameter sampled; --, not measured]

\begin{tabular}{|c|c|c|c|c|c|c|c|c|}
\hline \multirow{2}{*}{$\begin{array}{l}\text { Station } \\
\text { number }\end{array}$} & \multirow{2}{*}{$\begin{array}{c}\text { Map } \\
\text { number } \\
\text { (fig. 1) }\end{array}$} & \multirow{2}{*}{ Station name } & \multicolumn{4}{|c|}{ Continuous } & \multicolumn{2}{|c|}{ Instantaneous } \\
\hline & & & Salinity & Discharge & Velocity & Stage & Discharge & Sediment \\
\hline 07385790 & 1 & $\begin{array}{l}\text { Charenton Drainage Canal at } \\
\text { Baldwin }\end{array}$ & -- & $X$ & $\mathrm{X}$ & $\mathrm{X}$ & $\mathrm{X}$ & $\mathrm{X}$ \\
\hline 294551091422600 & 2 & $\begin{array}{l}\text { Gulf Intracoastal Waterway west of } \\
\text { Jaws Bay near Cypremort }\end{array}$ & -- & -- & -- & -- & $\mathrm{X}$ & $\mathrm{X}$ \\
\hline 07381680 & 3 & $\begin{array}{l}\text { Gulf Intracoastal Waterway east of } \\
\text { Jaws Bay west of Franklin }\end{array}$ & -- & -- & -- & -- & $\mathrm{X}$ & $\mathrm{X}$ \\
\hline 07381670 & 4 & $\begin{array}{l}\text { Gulf Intracoastal Waterway at } \\
\text { Bayou Sale Ridge near Franklin }\end{array}$ & -- & $\mathrm{X}$ & $\mathrm{X}$ & $\mathrm{X}$ & $\mathrm{X}$ & $\mathrm{X}$ \\
\hline 07381590 & 5 & Wax Lake Outlet at Calumet & -- & $\mathrm{X}$ & $\mathrm{X}$ & $\mathrm{X}$ & $\mathrm{X}$ & $\mathrm{X}$ \\
\hline 073816614 & 6 & $\begin{array}{l}\text { Gulf Intracoastal Waterway east of } \\
\text { Wax Lake Outlet near Calumet }\end{array}$ & -- & -- & -- & -- & $\mathrm{X}$ & $\mathrm{X}$ \\
\hline 293931091145200 & 7 & $\begin{array}{l}\text { Gulf Intracoastal Waterway at mile } \\
99 \text { south of Morgan City }\end{array}$ & -- & -- & -- & -- & $\mathrm{X}$ & $\mathrm{X}$ \\
\hline 07381600 & 8 & $\begin{array}{l}\text { Lower Atchafalaya River at } \\
\text { Morgan City }\end{array}$ & -- & $X$ & $\mathrm{X}$ & $\mathrm{X}$ & $\mathrm{X}$ & -- \\
\hline 073816501 & 9 & $\begin{array}{l}\text { Avoca Island Cutoff south of } \\
\text { Morgan City }\end{array}$ & -- & -- & -- & -- & $\mathrm{X}$ & $\mathrm{X}$ \\
\hline 073816503 & 10 & $\begin{array}{l}\text { Bayou Penchant south of } \\
\text { Morgan City }\end{array}$ & -- & $\mathrm{X}$ & $\mathrm{X}$ & $\mathrm{X}$ & $X$ & $\mathrm{X}$ \\
\hline 073814675 & 11 & $\begin{array}{l}\text { Bayou Boeuf at Railroad Bridge } \\
\text { at Amelia }\end{array}$ & -- & $\mathrm{X}$ & $\mathrm{X}$ & $\mathrm{X}$ & $\mathrm{X}$ & $\mathrm{X}$ \\
\hline 073816505 & 12 & $\begin{array}{l}\text { Gulf Intracoastal Waterway near } \\
\text { Bay Wallace east of Morgan City }\end{array}$ & -- & -- & -- & -- & $X$ & $\mathrm{X}$ \\
\hline 293400090432000 & 13 & $\begin{array}{l}\text { Gulf Intracoastal Waterway west } \\
\text { of Houma Navigation Canal at } \\
\text { Houma }\end{array}$ & -- & -- & -- & -- & $\mathrm{X}$ & $\mathrm{X}$ \\
\hline 07381331 & 14 & $\begin{array}{l}\text { Gulf Intracoastal Waterway } \\
\text { at Houma }\end{array}$ & -- & $\mathrm{X}$ & $\mathrm{X}$ & $\mathrm{X}$ & $\mathrm{X}$ & $\mathrm{X}$ \\
\hline 07381235 & 15 & $\begin{array}{l}\text { Gulf Intracoastal Waterway west of } \\
\text { Bayou Lafourche at Larose }\end{array}$ & -- & $\mathrm{X}$ & $\mathrm{X}$ & $\mathrm{X}$ & $\mathrm{X}$ & $\mathrm{X}$ \\
\hline 293408090230400 & 16 & $\begin{array}{l}\text { Gulf Intracoastal Waterway east of } \\
\text { Bayou Lafourche at Larose }\end{array}$ & -- & -- & -- & -- & $\mathrm{X}$ & $\mathrm{X}$ \\
\hline 295501090190400 & 17 & $\begin{array}{l}\text { Davis Pond Freshwater Diversion } \\
\text { near Boutte }\end{array}$ & -- & $\mathrm{X}$ & $\mathrm{X}$ & $\mathrm{X}$ & -- & -- \\
\hline 295124089542100 & 18 & $\begin{array}{l}\text { Caernarvon Outfall Channel at } \\
\text { Caernarvon }\end{array}$ & -- & $\mathrm{X}$ & $\mathrm{X}$ & $\mathrm{X}$ & -- & -- \\
\hline \multirow[t]{3}{*}{07387040} & 19 & Vermilion Bay near Cypremort Point & $\mathrm{x}$ & -- & -- & -- & -- & -- \\
\hline & 20 & TV04-04R $^{1}$ & $\mathrm{x}$ & -- & -- & -- & -- & -- \\
\hline & 21 & TE28-07R ${ }^{1}$ & $\mathrm{x}$ & -- & -- & -- & -- & -- \\
\hline 07381349 & 22 & $\begin{array}{l}\text { Caillou Lake (Sister Lake) } \\
\text { southwest of Dulac }\end{array}$ & $\mathrm{x}$ & -- & -- & -- & -- & -- \\
\hline 073813498 & 23 & Caillou Bay southwest of Cocodrie & $\mathrm{x}$ & -- & -- & -- & -- & -- \\
\hline 073802375 & 24 & Lake Salvador near Lafitte & $\mathrm{X}$ & -- & -- & -- & -- & -- \\
\hline 07380335 & 25 & Little Lake near Cutoff & $\mathrm{x}$ & -- & -- & -- & -- & -- \\
\hline 07380251 & 26 & Barataria Bay north of Grand Isle & $\mathrm{X}$ & -- & -- & -- & -- & -- \\
\hline 073802516 & 27 & Barataria Pass at Grand Isle & $\mathrm{X}$ & -- & -- & -- & -- & -- \\
\hline
\end{tabular}

${ }^{1}$ Gages operated by the Coastal Protection and Restoration Authority. Data can be accessed at http://cims.coastal.la.gov/DataDownload/DataDownload. aspx?type=hydro_hourly under hourly hydrographic data. 
Instantaneous measurements were made with a 600or 1,200-kilohertz boat-mounted acoustic Doppler current profiler (ADCP, RD Instruments, San Diego, California, USA) by following standard USGS protocol (Simpson and Oltmann, 1993). Concurrent with the instantaneous discharge measurements, suspended sediments at the same location in the GIWW were sampled at points in the center, left, and right of the channel cross-section with a depth-integrating sampler (Edwards and Glysson, 1999). There are corresponding suspended-sediment measurements for most but not every discharge measurement.

Flow direction is highly variable in this low-gradient coastal area; a sign convention was used to indicate streamflow direction. To the west of Morgan City, positive flow is to the west and south towards the Gulf of Mexico. To the east of Morgan City, positive flow is to the east and south, with the exception of the Avoca Island Cutoff where positive flow is to the northeast.

Salinity data were tabulated from stations located in the upper, middle, and lower parts of the hydrological basins with sondes recording salinity continuously at a single location in the water column. These stations are part of long-standing monitoring programs not associated with this study. Some of the stations are operated by USGS, and others are operated by Coastal Protection and Restoration Authority (Coastal Protection and Restoration Authority, 2014). Not all stations were operational for all of the selected years; some had incomplete records.

Stage and discharge of source waters were used to understand factors driving flow in the GIWW. To determine how the stage of the LAR influenced flow along the GIWW, the instantaneous discharge measurements at a given station made between 1997 and 2008 were averaged for four classes of stage of the LAR at Morgan City (site 8), all measured against the North American Vertical Datum of 1988: (1) 2.99 feet (ft) or less, (2) between 3.00 and 3.99 $\mathrm{ft}$, (3) between 4.00 and $5.49 \mathrm{ft}$, and (4) $5.50 \mathrm{ft}$ or greater. The majority of measurements were made when the stage of LAR at Morgan City (site 8) was less than $4 \mathrm{ft}$, but a substantial number of measurements were made above this stage. To determine how discharge of source waters influence flow along the GIWW, monthly average discharge in source waters was correlated with monthly average discharge at sites recording discharge continuously by using Pearson correlation coefficients.

To estimate the interannual variability of the streamflow in the GIWW, the long-term average conditions and years exhibiting extreme variations in LAR streamflow, with contrasting stage hydrographs, were selected for analysis (fig. 2). Stage of the LAR at Morgan City (site 8) was averaged for the period 1997-2008 to represent long-term averages. The year 1993 represented conditions of sustained high water with higher than average water levels throughout most of the year, not just during the spring. The spring stage was not unusually high in 1993. The years 2000 and 2006 were examples of low water years when stage remained below

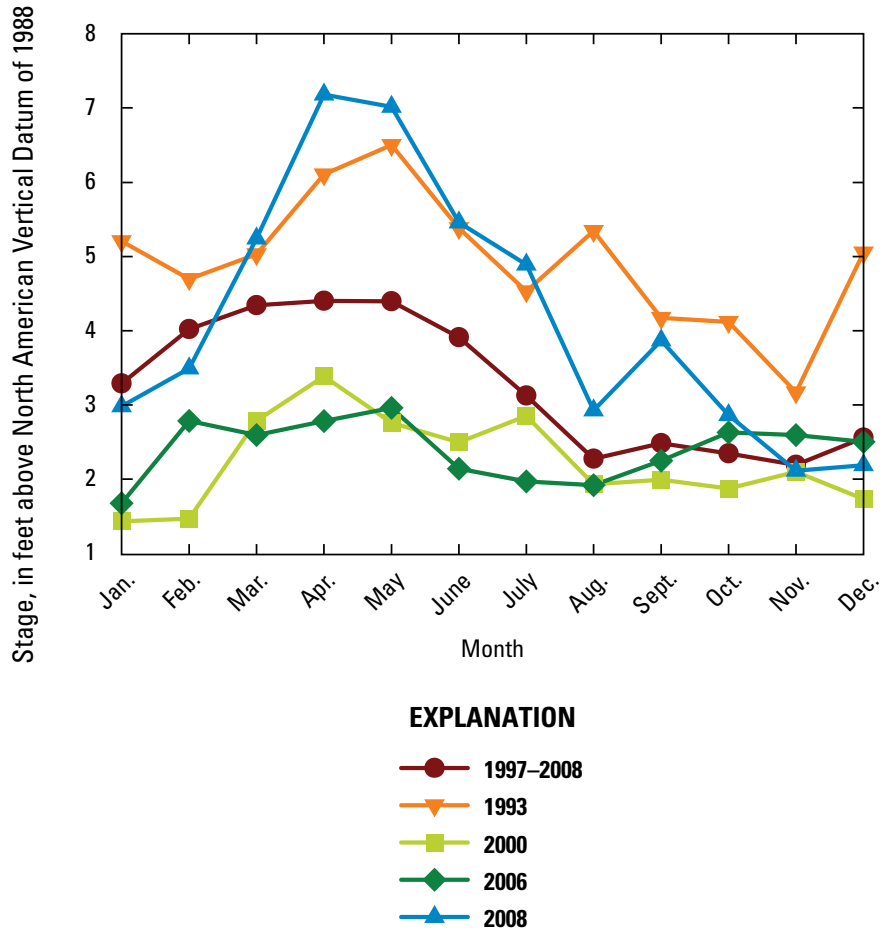

Figure 2. Monthly average stage of the Lower Atchafalaya River at Morgan City, Louisiana (average [1997-2008]; sustained high water [1993]; low water [2000, 2006]; and peak flood [2008]).

average for most of the year, including the normal spring flood period. The year 2008 was a year with a peak flood, a period when stage of the LAR was exceptionally high during the spring. Monthly average discharge of the Atchafalaya River at Simmesport (U.S. Army Corps of Engineers, 2009) and precipitation in the south-central climate division of Louisiana at Morgan City (National Oceanic and Atmospheric Administration, 2009) for these years are shown in table 2 to provide context for background conditions.

Discharge is measured continuously at only three stations along the GIWW. For these stations it was possible to directly compute monthly average discharge for typical and unusual water years. Monthly average discharge data for these stations were calculated for the period 2003-8 and for 2006 and 2008. Continuous data collected prior to 2003 were not tabulated because almost no velocity gages were operating before the fall of 1999, and continuous data were not collected at most stations until after 2002.

For the majority of locations along the GIWW, only instantaneous discharge measurements were available. An indirect method was needed to estimate the interannual variability in discharge along the GIWW. Daily 8 a.m. stage data of the LAR at Morgan City (site 8) (U.S. Army Corps of Engineers, 2009) for 1993 and for all years between 1997 and 2008 were compiled and assumed to be representative of daily 
Table 2. Monthly average discharge of the Atchafalaya River at Simmesport, Louisiana, and monthly average precipitation at Morgan City, Louisiana, for indicated time periods (average [1997-2008]; sustained high water [1993]; low water [2000; 2006]; and peak flood [2008]).

[ft $\mathrm{ft}^{3} / \mathrm{s}$, cubic feet per second]

\begin{tabular}{|c|c|c|c|c|c|c|c|c|c|c|}
\hline & \multicolumn{2}{|c|}{$\begin{array}{l}\text { Average } \\
\text { (1997-2008) }\end{array}$} & \multicolumn{2}{|c|}{$\begin{array}{l}\text { Sustained high } \\
\text { water year } \\
\text { (1993) }\end{array}$} & \multicolumn{2}{|c|}{$\begin{array}{c}\text { Low water year } \\
\text { (2000) }\end{array}$} & \multicolumn{2}{|c|}{$\begin{array}{l}\text { Low water year } \\
\text { (2006) }\end{array}$} & \multicolumn{2}{|c|}{$\begin{array}{l}\text { Peak flood year } \\
\text { (2008) }\end{array}$} \\
\hline & $\begin{array}{c}\text { Discharge } \\
\left(\mathrm{ft}^{3} / \mathrm{s} \times\right. \\
\mathbf{1 , 0 0 0 )}\end{array}$ & $\begin{array}{l}\text { Precipi- } \\
\text { tation } \\
\text { (inches) }\end{array}$ & $\begin{array}{c}\text { Discharge } \\
\left(\mathrm{ft}^{3} / \mathrm{s} \times\right. \\
1,000)\end{array}$ & $\begin{array}{c}\text { Precipi- } \\
\text { tation } \\
\text { (inches) }\end{array}$ & $\begin{array}{c}\text { Discharge } \\
\left(\mathbf{f t}^{3} / \mathbf{s} \times\right. \\
\mathbf{1 , 0 0 0 )}\end{array}$ & $\begin{array}{c}\text { Precipi- } \\
\text { tation } \\
\text { (inches) }\end{array}$ & $\begin{array}{c}\text { Discharge } \\
\left(\mathbf{f t}^{3} / \mathbf{s} \times\right. \\
\mathbf{1 , 0 0 0 )}\end{array}$ & $\begin{array}{c}\text { Precipi- } \\
\text { tation } \\
\text { (inches) }\end{array}$ & $\begin{array}{c}\text { Discharge } \\
\left(\mathrm{ft}^{3} / \mathrm{s} \times\right. \\
1,000)\end{array}$ & $\begin{array}{c}\text { Precipita- } \\
\text { tion } \\
\text { (inches) }\end{array}$ \\
\hline Jan. & 248 & 5.00 & 365 & 3.61 & 97 & 2.68 & 125 & 2.65 & 207 & 6.75 \\
\hline Feb. & 282 & 4.10 & 293 & 2.81 & 94 & 0.88 & 213 & 3.87 & 267 & 2.95 \\
\hline Mar. & 326 & 3.74 & 369 & 5.84 & 221 & 4.03 & 188 & 0.34 & 381 & 2.6 \\
\hline Apr. & 338 & 3.77 & 472 & 8.76 & 252 & 0.92 & 184 & 6.54 & 586 & 2.11 \\
\hline May & 315 & 3.71 & 492 & 8.65 & 168 & 0.72 & 208 & 1.71 & 472 & 5.48 \\
\hline June & 262 & 8.10 & 321 & 4.32 & 179 & 6.05 & 129 & 1.75 & 345 & 4.4 \\
\hline July & 211 & 5.86 & 290 & 6.02 & 211 & 5.36 & 98 & 9.07 & 302 & 3.19 \\
\hline Aug. & 141 & 5.04 & 342 & 3.07 & 109 & 3.37 & 76 & 6.23 & 177 & 8.69 \\
\hline Sept. & 120 & 6.35 & 231 & 4.38 & 78 & 5.23 & 80 & 4.08 & 198 & 11.13 \\
\hline Oct. & 122 & 4.72 & 254 & 3.82 & 79 & 1.25 & 131 & 7.18 & 144 & 0.66 \\
\hline Nov. & 133 & 4.47 & 212 & 4.00 & 102 & 13.43 & 179 & 2.36 & 99 & 2.26 \\
\hline Dec. & 195 & 4.22 & 325 & 3.28 & 139 & 3.09 & 173 & 10.87 & 144 & 4.24 \\
\hline Jan.-June ${ }^{1}$ & 295 & 28.42 & 386 & 33.99 & 168 & 15.28 & 174 & 16.86 & 376 & 24.29 \\
\hline July-Dec. & 153 & 30.67 & 276 & 24.57 & 120 & 31.73 & 123 & 39.79 & 177 & 30.17 \\
\hline
\end{tabular}

${ }^{1}$ Discharge data are 6-month averages; precipitation data are 6-month totals.

stage. The percentage of time stage remained within each of the previously described four classes for which instantaneous discharge was averaged and was calculated for the January through June and July through December periods for the years 1993, 2006, and 2008 and for the period 1997-2008 (the average period). Average discharge was estimated at each location for each of these time periods by using the percentage of time the stage of the LAR at Morgan City (site 8) remained within a class for that time period and 6-month interval and the average measured instantaneous discharge for the same stage class at that location. Average discharge was determined for the January-June (spring flood) and for July-December (seasonal low water) periods.

To evaluate possible long-term trends in water flowing in the GIWW, stage exceedance curves for daily stage of the LAR at Morgan City (site 8) were prepared by averaging the daily 8 a.m. stage in 10-year intervals starting in 1940 and continuing through 2008 . The percent time a specified stage was exceeded was calculated in 1-ft increments. Because streamflow in the GIWW is related to stage of the LAR at Morgan City (site 8), this analysis made it possible to determine whether the amount of water flowing from the Atchafalaya River into the GIWW has changed over time.
Suspended-sediment concentrations at selected sites were examined by making boxplots of the individual measurements. Median values; the 10th, 25th, 75th, and 90th percentiles; and outliers were determined.

The influence of freshwater flowing in the GIWW on adjacent wetlands and surface waters was evaluated by comparing surface-water salinity at select locations in the intradistributary basins that the GIWW crosses in south-central Louisiana. Intradistributary basins are the basins bordered by current and historic former channels of the Mississippi River. Natural, higher elevation levees from the former river channels provided hydrologic barriers to cross-basin flow prior to construction of the GIWW. In each basin, 2 to 4 stations where salinity was collected continuously through routine monitoring programs were selected for evaluation (fig. 1, table 1). Average monthly salinity for the period 1997-2008, the year with sustained high water (1993), a low water year (2000), and a peak flood year (2008) were tabulated. The low water year in 2000, rather than in 2006, was selected to show patterns that existed prior to operation of a freshwater diversion in the Barataria Basin. The influence the Davis Pond Freshwater Diversion Structure had on salinity in the Barataria Basin was evaluated by comparing salinity for low water years 
in 2000 and 2006. Operation of the freshwater diversion began in 2004; the diversion inflow influenced basin salinity in 2006. Not all stations were operational for all of the selected years; some had incomplete records.

\section{Discharge, Suspended Sediment, and Salinity}

Analysis of more than 10 years of instantaneous and continuous data demonstrates that the GIWW functions as a distributary of river water laterally across a wide area of coastal Louisiana. The GIWW conveys freshwater and suspended sediments originating from the LAR and WLO to intradistributary basins and wetlands at least 30 and 50 miles west and east, respectively, of Morgan City. Predictably, discharge along the GIWW is highest at stations closest to the LAR and WLO and then decreases with increasing distance from these sources. In general, discharge increased steadily as stage of the source waters increased; discharge at many locations in the GIWW becomes predictable when stage of the
LAR at Morgan City is between 3 and $4 \mathrm{ft}$ or higher. As shown in Swarzenski (2003), flow in the GIWW is passive, following naturally occurring hydraulic gradients. These are generated by differences in water-surface elevation between the source waters and the GIWW. For some parts of coastal Louisiana too far away from the Mississippi River, the GIWW is the only means of getting river water to adjacent surface waters.

\section{Discharge}

Discharge measurements made between 1997 and 2008 are summarized in table 3; mean and median values and maximum and minimum values are included. Discharge in the GIWW decreased with distance from source waters. The highest single discharge was 61,100 cubic feet per second $\left(\mathrm{ft}^{3} / \mathrm{s}\right)$ at Avoca Island Cutoff south of Morgan City (site 9). Substantial reverse discharge was measured at least once at all stations, with the exception of the GIWW at Bayou Sale Ridge near Franklin (site 4) and east of Jaws Bay west of Franklin (site 3) where the lowest measurements were 20 and about $2,000 \mathrm{ft}^{3} / \mathrm{s}$, respectively (table 3 ), but discharge was still to the west.

Table 3. Summary of instantaneous discharge measurements at selected sites along or near the Gulf Intracoastal Waterway in southcentral Louisiana, 1997-2008.

[Discharge measurements are in cubic feet per second; positive flow is towards the Gulf of Mexico and away from Morgan City; \pm , plus or minus; GIWW, Gulf Intracoastal Waterway]

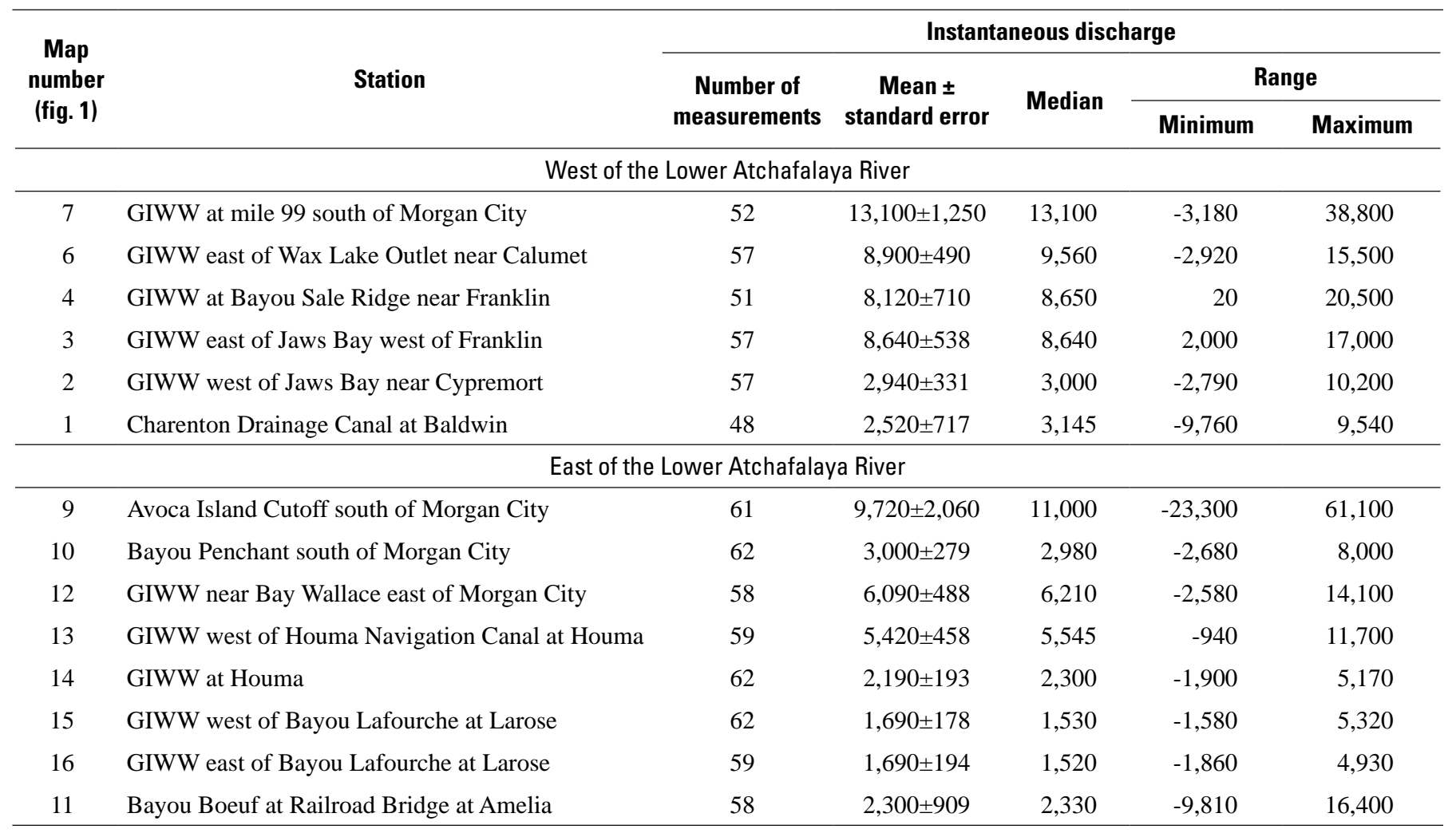


Discharge in the GIWW between the LAR and WLO was almost always to the west, but some of the water entering the GIWW at mile 99 south of Morgan City (site 7) exited the GIWW and flowed south towards the Gulf of Mexico rather than continuing west in the GIWW towards the WLO as LAR stage increased. In the GIWW at mile 99 south of Morgan City (site 7), discharge to the west increased rapidly as stage of the LAR increased, but the discharge exiting the GIWW east of WLO near Calumet (site 6) only increased gradually, or even decreased, as river stage increased (table 4). At stages above $5.5 \mathrm{ft}, 31,500 \mathrm{ft}^{3} / \mathrm{s}$ on average entered the GIWW; of this amount, $11,400 \mathrm{ft}^{3} / \mathrm{s}$ on average reached the WLO. The balance flowed south towards the Gulf of Mexico.

West of the WLO, the discharge also was to the west and also increased with increasing stage. Much of the water entering the GIWW reached Jaws Bay rather than dispersing into the adjacent wetlands. Above $5.5 \mathrm{ft}, 17,900 \mathrm{ft} / \mathrm{s}$ flowed in the GIWW at Bayou Sale Ridge near Franklin (site 4) and about $14,500 \mathrm{ft}^{3} / \mathrm{s}$, or more than 75 percent of this flow, reached the GIWW east of Jaws Bay west of Franklin (site 3)

Table 4. Discharge at selected locations in the Gulf Intracoastal Waterway and adjacent waterways averaged for indicated stage increments of the Lower Atchafalaya River at Morgan City, 1997-2008.

[Positive flow is towards the Gulf of Mexico and away from Morgan City; NAVD 88, North American Vertical Datum of 1988; \pm , plus or minus; GIWW, Gulf Intracoastal Waterway; <, less than; >, greater than]

\begin{tabular}{|c|c|c|c|c|c|c|}
\hline $\begin{array}{c}\text { Stage of } \\
\text { the Lower } \\
\text { Atchafalaya River } \\
\text { at Moraan City }\end{array}$ & \multicolumn{6}{|c|}{$\begin{array}{c}\text { Mean discharge ( } \pm 1 \text { standard error) } \\
\text { (cubic feet per second) }\end{array}$} \\
\hline \multicolumn{7}{|c|}{ Stations west of the Lower Atchafalaya River } \\
\hline \multirow[t]{2}{*}{ Map number } & 7 & 6 & 4 & 3 & 2 & 1 \\
\hline & $\begin{array}{l}\text { GIWW at } \\
\text { mile } 99 \text { south } \\
\text { of Morgan City }\end{array}$ & $\begin{array}{l}\text { GIWW east of } \\
\text { Wax Lake Outlet } \\
\text { near Calumet }\end{array}$ & $\begin{array}{l}\text { GIWW at Bayou } \\
\text { Sale Ridge } \\
\text { near Franklin }\end{array}$ & $\begin{array}{l}\text { GIWW east of } \\
\text { Jaws Bay west } \\
\text { of Franklin }\end{array}$ & $\begin{array}{c}\text { GIWW west of } \\
\text { Jaws Bay near } \\
\text { Cypremort }\end{array}$ & $\begin{array}{c}\text { Charenton } \\
\text { Drainage Canal } \\
\text { at Baldwin }\end{array}$ \\
\hline$<2.99$ & $5,510 \pm 925$ & $6,350 \pm 695$ & $3,560 \pm 491$ & $6,640 \pm 385$ & $2,560 \pm 491$ & $3,230 \pm 915$ \\
\hline 3.0-3.99 & $13,600 \pm 805$ & $9,380 \pm 717$ & $9,500 \pm 348$ & $9,520 \pm 539$ & $3,980 \pm 468$ & $3,240 \pm 1,320$ \\
\hline $4.0-5.49$ & $19,700 \pm 1,060$ & $12,100 \pm 506$ & $13,600 \pm 537$ & $12,200 \pm 628$ & $3,660 \pm 736$ & $2,370 \pm 1,660$ \\
\hline$>5.5$ & $31,500 \pm 2,690$ & $11,400 \pm 979$ & $17,900 \pm 1,780$ & $14,500 \pm 562$ & $4,000 \pm 1,150$ & $-5,620 \pm 2,740$ \\
\hline \multicolumn{7}{|c|}{ Stations east of the Lower Atchafalaya River } \\
\hline \multirow[t]{2}{*}{ Map number } & 9 & 10 & 12 & 13 & 11 & \\
\hline & $\begin{array}{l}\text { Avoca Island } \\
\text { Cutoff south of } \\
\text { Morgan City }\end{array}$ & $\begin{array}{c}\text { Bayou Penchant } \\
\text { south of Morgan } \\
\text { City }\end{array}$ & $\begin{array}{l}\text { GIWW near Bay } \\
\text { Wallace east of } \\
\text { Morgan City }\end{array}$ & $\begin{array}{c}\text { GIWW west } \\
\text { of Houma } \\
\text { Navigation Canal } \\
\text { at Houma }\end{array}$ & $\begin{array}{c}\text { Bayou Boeuf at } \\
\text { Railroad Bridge } \\
\text { at Amelia }\end{array}$ & \\
\hline$<2.99$ & $2,670 \pm 2,900$ & $1,430 \pm 276$ & $3,330 \pm 584$ & $2,510 \pm 423$ & $1,010 \pm 1,440$ & \\
\hline 3.0-3.99 & $10,700 \pm 3,270$ & $4,170 \pm 475$ & $6,480 \pm 626$ & $6,180 \pm 561$ & $871 \pm 1,540$ & \\
\hline $4.0-5.49$ & $17,300 \pm 2,970$ & $4,710 \pm 456$ & $8,930 \pm 391$ & $8,480 \pm 625$ & $6,320 \pm 1,400$ & \\
\hline$>5.5$ & $22,700 \pm 9,630$ & $4,720 \pm 650$ & $11,100 \pm 573$ & $9,990 \pm 845$ & $2,850 \pm 2,330$ & \\
\hline \multirow[t]{2}{*}{ Map number } & 14 & 15 & 16 & & & \\
\hline & $\begin{array}{l}\text { GIWW at } \\
\text { Houma }\end{array}$ & $\begin{array}{l}\text { GIWW west of } \\
\text { Bayou Lafourche } \\
\text { at Larose }\end{array}$ & $\begin{array}{l}\text { GIWW east of } \\
\text { Bayou Lafourche } \\
\text { at Larose }\end{array}$ & & & \\
\hline$<2.99$ & $1,550 \pm 272$ & $905 \pm 221$ & $873 \pm 256$ & & & \\
\hline 3.0-3.99 & $2,210 \pm 389$ & $1,740 \pm 304$ & $1,830 \pm 364$ & & & \\
\hline $4.0-5.49$ & $2,990 \pm 317$ & $2,770 \pm 416$ & $2,650 \pm 414$ & & & \\
\hline$>5.5$ & $3,630 \pm 405$ & $2,730 \pm 366$ & $2,690 \pm 386$ & & & \\
\hline
\end{tabular}


(table 4). At low river stage, there appeared to be inflow into the GIWW between Bayou Sale Ridge and Jaws Bay that did not originate from the WLO. Much of the water entering the GIWW at the WLO discharged into Jaws Bay. Discharge in the GIWW west of Jaws Bay near Cypremort (site 2) increased when stage of the LAR reached $3 \mathrm{ft}$ but then remained relatively constant at about $4,000 \mathrm{ft}^{3} / \mathrm{s}$, with further increases in LAR stage. The Charenton Drainage Canal at Baldwin (site 1) contributed around 2,400 to 3,300 $\mathrm{ft}^{3} / \mathrm{s}$ to the opening to Jaws Bay at most stages of the LAR. At the highest LAR stage, net discharge in the Charenton Drainage Canal at Baldwin (site 1) was found to be in an inland direction.

East of Morgan City, water entered the GIWW from the LAR primarily through the Avoca Island Cutoff. Additional water entered the GIWW through Bayou Boeuf at Railroad Bridge at Amelia (site 11). Stage of the LAR at Morgan City (site 8) influenced flows as far away as Bayou Lafourche at Larose. Bayou Boeuf at Railroad Bridge at Amelia (site 11) usually contributed water to the GIWW regardless of stage of the LAR at Morgan City (site 8) (table 4). At high river stage, the Avoca Island Cutoff (site 9) supplied the majority of water to the GIWW (table 4). Discharge here increased as stage of the LAR at Morgan City (site 8) increased. Discharge in the Avoca Island Cutoff south of Morgan City (site 9) averaged 22,700 $\mathrm{ft}^{3} / \mathrm{s}$ when stage of the LAR at Morgan City (site 8) exceeded $5.5 \mathrm{ft}$. Some of the water flowed from the Avoca Island Cutoff into Bayou Penchant. Discharge in the GIWW near Bay Wallace east of Morgan City (site 12) increased as stage of the LAR at Morgan City increased and averaged $11,100 \mathrm{ft}^{3} / \mathrm{s}$ towards Houma when stage was above $5.5 \mathrm{ft}$. Discharge in the GIWW west of the HNC at Houma (site 13) averaged about 10,000 $\mathrm{ft}^{3} / \mathrm{s}$ under the same conditions.

The majority of the water in the GIWW reaching the $\mathrm{HNC}$ from the west flowed south into the HNC; discharge in the GIWW at Houma (site 14) was considerably lower than west of the HNC at Houma (site 13); for example, at stages of the LAR at Morgan City (site 8) greater than $5.5 \mathrm{ft}$, discharge continuing east across the HNC and towards Bayou Lafourche averaged about 3,600 $\mathrm{ft}^{3} / \mathrm{s}$, or just over one-third of the amount reaching the HNC from the west. Discharge in the GIWW at Houma (site 14) increased with increasing stage of the LAR at Morgan City (site 8). Farther east, discharge on both sides of Bayou Lafourche was similar for all four classes of LAR stage. Discharge in the GIWW west (site 15) and east (site 16) of Bayou Lafourche at Larose increased with increasing stage of the LAR at Morgan City up to $4 \mathrm{ft}$ but remained relatively constant at about $2,700 \mathrm{ft}^{3} / \mathrm{s}$ when stage of the LAR exceeded this threshold. A small amount of water enters the GIWW from Bayou Lafourche on the northwest side, and a similar amount flows from the GIWW into Bayou Lafourche along the southeast side (Swarzenski, 2003).

Discharge at most locations on the GIWW increased as stage of the LAR at Morgan City (site 8) increased. This was demonstrated in the previous section by averaging instantaneous measurements made for four stage increments of the LAR at Morgan City (site 8) (table 4). To what degree source waters controlled discharge at various locations along the GIWW also can be assessed by comparing monthly averaged discharge from continuously operating gages in the GIWW to that in the WLO and LAR (figs. 3 and 4). Significant $(p<0.001)$ high correlation coefficients in what at least east of Morgan City are fairly open hydrologic systems demonstrate how tightly flow along the GIWW is controlled by flows at the sources.

Discharge of source waters correlated significantly with discharge in the GIWW on both sides of Morgan City. To the west of the WLO, monthly average discharge in the GIWW at Bayou Sale Ridge near Franklin was highly correlated with monthly average discharge of the WLO at Calumet (site $5 ; r^{2}=0.95, p<0.001$ ) (fig. 3). Monthly average discharge in the GIWW near Bay Wallace east of Morgan City (site 12) increased linearly with increasing monthly average discharge of the LAR at Morgan City (site 8; $\mathrm{r}^{2}=0.92, \mathrm{p}<0.001$ ) and when river stage was $3 \mathrm{ft}$ or less above with monthly average discharge in Bayou Boeuf at Railroad Bridge at Amelia (site $11 ; \mathrm{r}^{2}=0.58, \mathrm{p}<0.001$ ) (fig. 4). When stage of the LAR at Morgan City (site 8) was below $3 \mathrm{ft}$, on average more than one-third of the discharge in the GIWW near Bay Wallace east of Morgan City (site 12) came from Bayou Boeuf at Railroad Bridge at Amelia (site 11). When flow of the LAR was low, the Verret subbasin became a major source of water, maintaining the eastward flow in the GIWW. Monthly average discharge in the GIWW at Houma (site 14) increased steadily with increases in monthly average discharge of the GIWW near Bay Wallace east of Morgan City (site 12; $\mathrm{r}^{2}=0.86$, $\mathrm{p}<0.001$ ) (fig. 4). Farther east, discharge in the GIWW west of Bayou Lafourche at Larose (site 15) was more weakly related to discharge in the GIWW near Bay Wallace east of Morgan City (site 12$)\left(\mathrm{r}^{2}=0.62, \mathrm{p}<0.001\right)$.

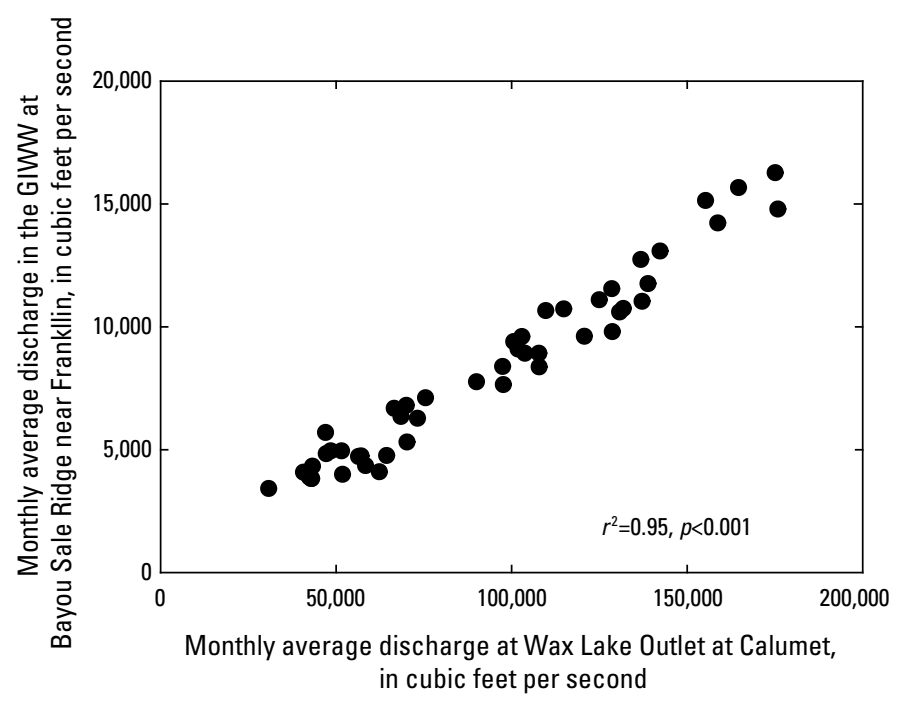

Figure 3. Relation between monthly average discharge in the Gulf Intracoastal Waterway (GIWW) at Bayou Sale Ridge near Franklin and monthly average discharge of the Wax Lake Outlet at Calumet. 

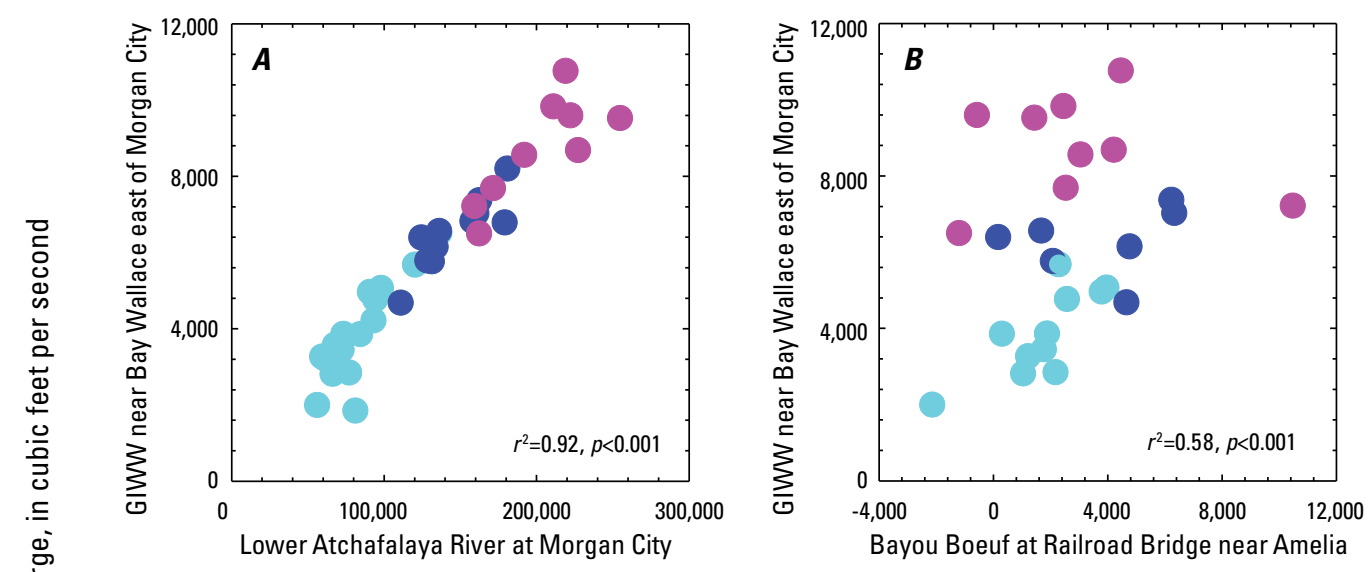

EXPLANATION
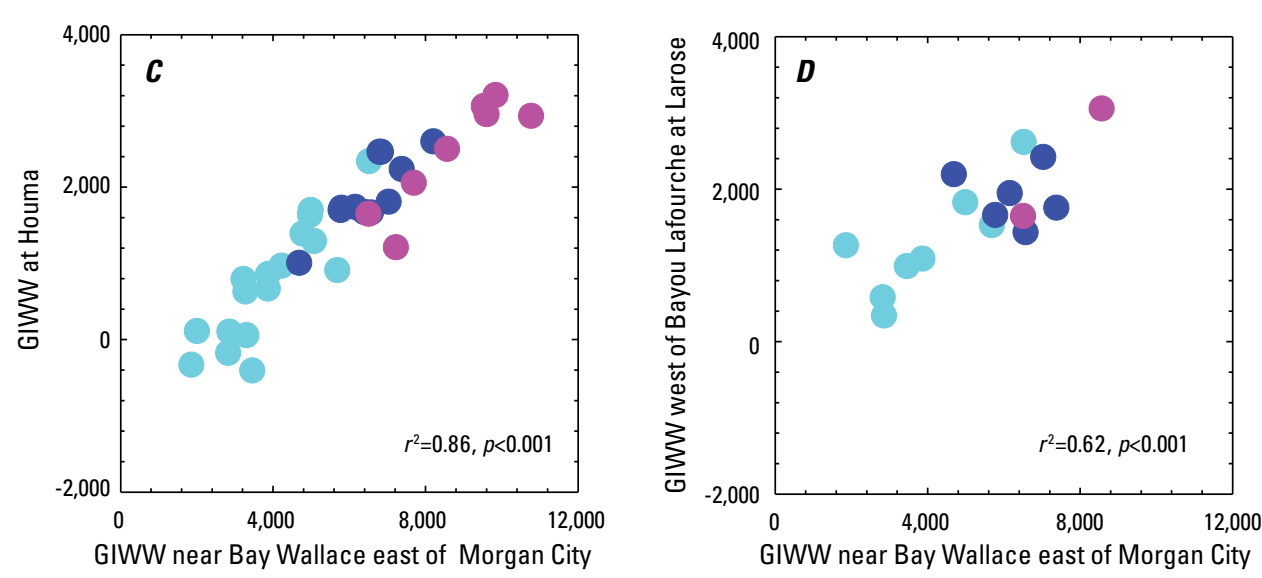

Monthly average discharge, in cubic feet per second

Figure 4. Relation between monthly average discharge in the Gulf Intracoastal Waterway (GIWW) near Bay Wallace east of Morgan City and monthly average discharge of the Lower Atchafalaya River at Morgan City or Bayou Boeuf at Railroad Bridge near Amelia (panels $A$ and $B$ ); graphs showing relation between monthly average discharge in the GIWW at Houma or west of Bayou Lafourche at Larose and monthly average discharge of the GIWW near Bay Wallace east of Morgan City (panels $C$ and $D$ ). Correlation in panel $B$ is only for a Lower Atchafalaya River stage of 3 feet or less North American Vertical Datum of 1988 (NAVD 88).

\section{Interannual Variability}

The amount of river water flowing along the GIWW depends on stages of the WLO and the LAR and will vary considerably from year to year depending on the hydrograph of those source waters. On average, hydraulic head differences between source waters and the GIWW are most pronounced during spring floods of the Atchafalaya River. This is the period when flows in the GIWW should be high. Year-to-year variations in Atchafalaya River flow, caused by droughts or large amounts of precipitation in the entire drainage basin, for example, also will influence flow in the GIWW.

The annual discharge of water flowing in the GIWW was greatest during the year with sustained high water of source waters (1993) (tables 5 and 6). This was the year when the most freshwater was delivered to coastal Louisiana through the GIWW. The steady above average discharge during the second half of the year, when stage of the LAR at Morgan City (site 8) remained anomalously high, was the primary difference; however, in just the first half of the year, the amount of water flowing in 1993 in the GIWW surpassed the amount of water under peak flood conditions of source waters in 2008. For example, the average discharge from January to June in 1993 was 15,500 ft $3 / \mathrm{s}$ in the GIWW at Bayou Sale Ridge near Franklin (site 4); during the peak flood year in 2008, discharge over the same time period was about 2,000 ft $3 / \mathrm{s}$ less (table 5). For the second half of the year, discharge at Bayou Sale Ridge near Franklin (site 4) was 12,100 ft $\mathrm{ft}^{3} / \mathrm{s}$ in 1993 but decreased to about $7,000 \mathrm{ft}^{3} / \mathrm{s}$ in 2008 . The pattern was the same to the east of Morgan City. Discharge in the GIWW near Bay Wallace east of Morgan City (site 12) during the first 6 months of 1993 averaged about $9,900 \mathrm{ft}^{3} / \mathrm{s}$, compared with $8,740 \mathrm{ft}^{3} / \mathrm{s}$ during the first 6 months of the peak flow year (2008) (table 6). In the second half of the year, discharge averaged 8,030 ft $3 / \mathrm{s}$ in 1993 compared with $5,220 \mathrm{ft}^{3} / \mathrm{s}$ in 2008 . The same trends also held at greater distances from the source waters, but the differences were less pronounced. To the west of Morgan City, discharge in the GIWW west of Jaws Bay near Cypremort (site 2) averaged 
Table 5. Estimated discharge in the Gulf Intracoastal Waterway at stations west of the Lower Atchafalaya River at Morgan City; data presented are for averages from 1997 to 2008, for a sustained high water year (1993), for a low water year (2006), and for a peak flood year (2008).

[Values are estimated by using average instantaneous discharge values shown in table 4 and the percent time the Lower Atchafalaya River at Morgan City was at the corresponding stage intervals for the indicated time period]

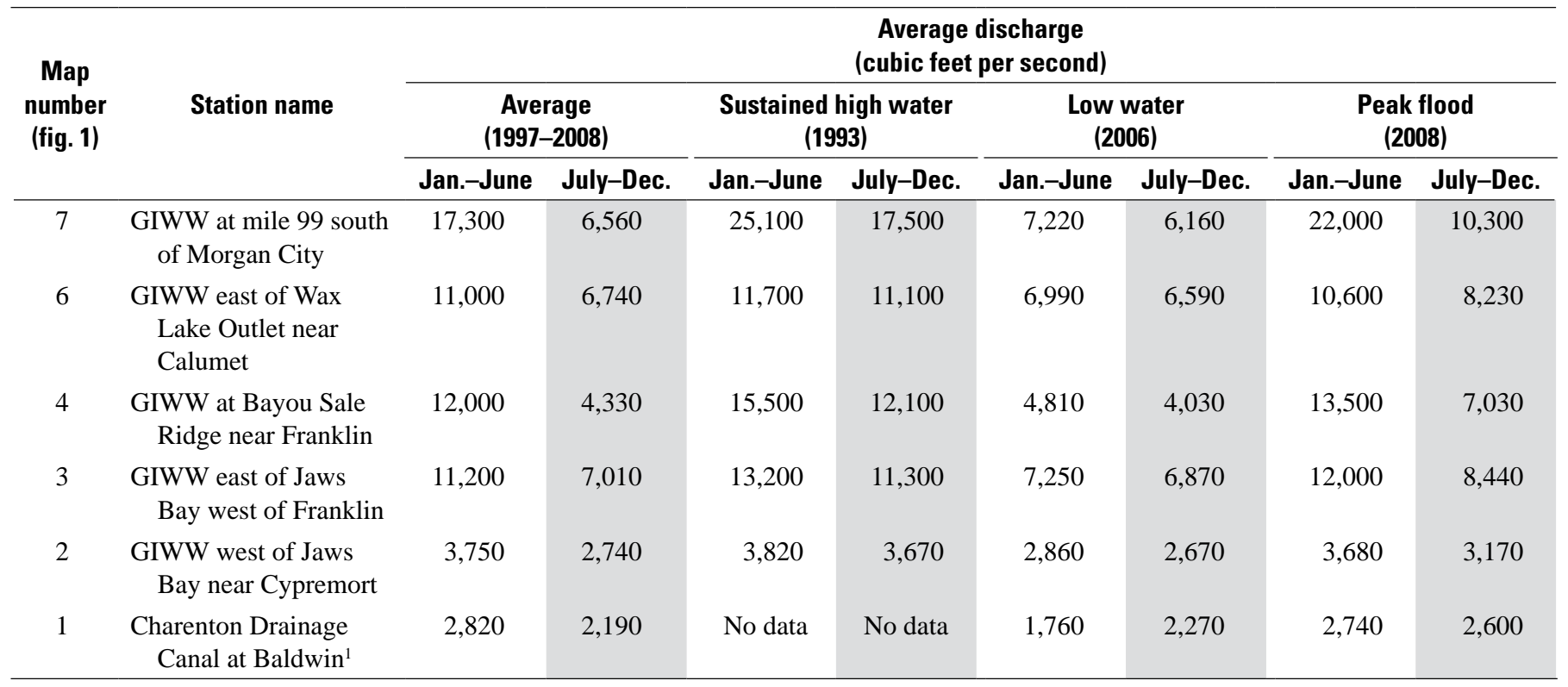

${ }^{1}$ Values calculated from continuous discharge gage, starting January 2002.

Table 6. Estimated discharge in the Gulf Intracoastal Waterway at stations east of the Lower Atchafalaya River at Morgan City; data presented are for averages from 1997 to 2008, for a sustained high water year (1993), for a low water year (2006), and for a peak flood year (2008).

[Values are estimated by using average instantaneous discharge values shown in table 4 and the percent time the Lower Atchafalaya River at Morgan City was at the corresponding stage intervals for the indicated time period; GIWW, Gulf Intracoastal Waterway]

\begin{tabular}{|c|c|c|c|c|c|c|c|c|c|}
\hline \multirow{3}{*}{$\begin{array}{c}\text { Map } \\
\text { number } \\
\text { (fig. 1) }\end{array}$} & \multirow{3}{*}{ Station name } & \multicolumn{8}{|c|}{$\begin{array}{c}\text { Average discharge } \\
\text { (cubic feet per second) }\end{array}$} \\
\hline & & \multicolumn{2}{|c|}{$\begin{array}{c}\text { Average } \\
(1997-2008)\end{array}$} & \multicolumn{2}{|c|}{$\begin{array}{c}\text { Sustained high water } \\
\text { (1993) }\end{array}$} & \multicolumn{2}{|c|}{$\begin{array}{l}\text { Low water } \\
\text { (2006) }\end{array}$} & \multicolumn{2}{|c|}{$\begin{array}{l}\text { Peak flood } \\
(2008)\end{array}$} \\
\hline & & Jan.-June & July-Dec. & Jan.-June & July-Dec. & Jan.-June & July-Dec. & Jan.-June & July-Dec \\
\hline 9 & $\begin{array}{l}\text { Avoca Island Cutoff Channel } \\
\text { south of Morgan City }\end{array}$ & 14,700 & 3,970 & 19,700 & 15,400 & 4,370 & 3,450 & 16,700 & 8,150 \\
\hline 10 & $\begin{array}{l}\text { Bayou Penchant south of } \\
\text { Morgan City }\end{array}$ & 4,450 & 1,790 & 4,710 & 4,370 & 2,010 & 1,640 & 4,160 & 2,810 \\
\hline 12 & $\begin{array}{l}\text { GIWW near Bay Wallace east } \\
\text { of Morgan City }\end{array}$ & 7,960 & 3,740 & 9,900 & 8,030 & 4,000 & 3,580 & 8,740 & 5,220 \\
\hline 13 & $\begin{array}{l}\text { GIWW west of Houma } \\
\text { Navigation Canal at Houma }\end{array}$ & 7,560 & 2,990 & 9,150 & 7,580 & 3,280 & 2,800 & 7,970 & 4,620 \\
\hline 14 & GIWW at Houma & 2,690 & 1,640 & 3,280 & 2,720 & 1,690 & 1,600 & 2,960 & 1,990 \\
\hline 15 & $\begin{array}{l}\text { GIWW west of Bayou } \\
\text { Lafourche at Larose }\end{array}$ & 2,370 & 1,010 & 2,740 & 2,410 & 1,080 & 973 & 2,350 & 1,470 \\
\hline 16 & $\begin{array}{l}\text { GIWW east of Bayou } \\
\text { Lafourche at Larose }\end{array}$ & 2,330 & 997 & 2,660 & 2,340 & 1,080 & 950 & 2,300 & 1,460 \\
\hline 11 & $\begin{array}{l}\text { Bayou Boeuf at Railroad } \\
\text { Bridge at Amelia }{ }^{1}\end{array}$ & 2,530 & 1,820 & No data & No data & 953 & 1,290 & 1,840 & 2,300 \\
\hline
\end{tabular}

\footnotetext{
${ }^{1}$ Values calculated from continuous discharge gage; record begins in February 2003.
} 
$3,820 \mathrm{ft}^{3} / \mathrm{s}$ during the first 6 months of 1993 and 3,680 $\mathrm{ft}^{3} / \mathrm{s}$ during the same time period in 2008 (table 5). In the GIWW at Houma (site 14), the discharge during the second half of the year was 2,720 ft $3 / \mathrm{s}$ in 1993 and 1,990 $\mathrm{ft}^{3} / \mathrm{s}$ in 2008 (table 6). The key to large inflows of freshwater to coastal wetlands through the GIWW is sustained high water of the source waters throughout an entire year. Peak floods can deliver large quantities of freshwater through the GIWW but only for short periods of time.

Conversely, annual discharge in the GIWW was substantially below average for the first 6 months of the year when stage of the LAR (site 8) remained low for most of the year, as occurred in 2006, but was not substantially different from average discharges during the second half of the year. Discharge in the GIWW at Bayou Sale Ridge near Franklin (site 4) averaged 12,000 ft $3 / \mathrm{s}$ for the first 6 months from 1997 to 2008 but only $4,810 \mathrm{ft}^{3} / \mathrm{s}$ during the same time period in 2006 (table 5). From July through December, discharge here averaged 4,330 ft $\mathrm{ft}^{3} / \mathrm{s}$ from 1997 to 2008 and 4,030 $\mathrm{ft}^{3} / \mathrm{s}$ in 2006. Discharge in the GIWW near Bay Wallace east of Morgan City (site 12) averaged 7,960 ft $3 / \mathrm{s}$ during the first 6 months of the year from 1997 to 2008 but only 4,000 ft $3 / \mathrm{s}$ during the same time period in 2006 (table 6). Discharge at site 12 in the second half of the year was 3,740 ft3 3 s from 1997 to 2008 and 3,580 ft $3 / \mathrm{s}$ in 2006. Farther from the sources of the water flowing into the GIWW, discharge in the GIWW both west and east of Bayou Lafourche at Larose (sites 15 and 16, respectively) averaged about $1,000 \mathrm{ft}^{3} / \mathrm{s}$ from July to December in 2006, very similar to the long-term average discharge from 1997 to 2008 during the same time period (table 6).

The previous values showing interannual variability in flow along the GIWW were generated by indirect methods, by using averages of all discrete measurements made between 1997 and 2008 for four stage classes of the LAR at Morgan City (site 8); thus, the values shown in tables 5 and 6 are estimated values. For the GIWW at the Bayou Sale Ridge near Franklin (site 4), the GIWW at Houma (site 14), and the GIWW west of Bayou Lafourche at Larose (site 15), direct tabulations of interannual variability in discharge were possible by using computed discharge records, although the period of record when continuous gaging stations were in operation was shorter. Comparisons between the two methods allow a qualitative assessment of the indirect method to estimate discharge on the GIWW. This is valuable because the majority of stations on the GIWW are ungaged and only instantaneous measurements are available.

Continuous discharge data for the same time periods also are shown for two controlled diversions of Mississippi River water. At these sites, river water is actively moved over and under flood control levees through control structures and into the adjacent estuarine waters and marshes to mitigate wetland loss. Even small amounts of river water are presumed to have beneficial effects on marshes and enhance restoration (Nyman, 2014; Coastal Protection and Restoration Authority, 2015). The comparison of controlled diversion discharge with the discharge in the GIWW is one measure of the potential of the GIWW for wetland restoration.

Methods used to estimate discharge indirectly (tables 5 and 6) both overestimated and underestimated computed discharge at these same sites by as much as 20-35 percent (tables 5-7). In general, the indirect method tended to overestimate discharge, but in the GIWW at Bayou Sale Ridge near Franklin (site 4), the direct calculations were higher for the first 6 months for the low water year 2006. As a first approximation, indirect methods of estimating discharge in the GIWW are useful, but direct measurements are preferable and needed to better quantify the amount of water being conveyed by the GIWW under hydrologically varying conditions.

Discharge in the GIWW was comparable to the controlled discharges at the diversion sites, and in at least one site (for example, at Bayou Sale Ridge at Franklin [site 4]), discharge was almost always much greater under all hydrological conditions. During the period 2003-8, average discharge in the GIWW at Houma (site 14) and west of Bayou Lafourche at Larose (site 15) was only $400-800 \mathrm{ft}^{3} / \mathrm{s}$ lower than at the two controlled diversions for the January-June period. This part of coastal Louisiana is too far away from the Mississippi River to benefit from controlled diversions on the river. The GIWW is the only means of getting river water to the area marshes; however, controlled diversions were better able to effectively discharge river water into coastal basins during years of below average flow, such as 2006 (table 7).

\section{Trends}

In addition to the short-term interannual variability in discharge along the GIWW that depends on the characteristics of a particular water year, long-term trends in hydrography of the LAR will also affect the magnitude and duration of discharge along the GIWW. These include changes in the length of time the LAR at Morgan City (site 8) remains above stages that induce predictable flow in the GIWW. This would change the duration in any given year that the GIWW effectively functions as a distributary of floodwaters of the Atchafalaya River. In the absence of direct discharge measurements reaching back in time, analysis of long-term trends of the stage of the LAR at Morgan City (site 8) is the only way to understand longterm trends in flow along the GIWW. Also of interest is whether relations between a given stage of the LAR at Morgan City (site 8) and the observed discharge at a selected point along the GIWW are changing over time.

The duration a given stage of the LAR at Morgan City (site 8) exceeded a given elevation increased from the 1940s to 2008 , most dramatically during the 1970 s (fig. 5). During the early 1970s, 3 consecutive years of high water occurred that likely contributed to the increase, but the shift persisted in the following decades, even late each year in November and October. Infilling of the river bed and the initial subaerial growth of the deltas at the mouth of the LAR and WLO, which would increase backwater effects, probably contributed to the shift. 
Table 7. Monthly average continuous discharge at stations with continuous index velocity measurements along the Gulf Intracoastal Waterway and at the Davis Pond and Caernarvon freshwater diversions; data presented are for averages from 2003 to 2008, for a low water year (2006), and for a peak flood year (2008).

[Discharge is in cubic feet per second; some months have only partial data; GIWW, Gulf Intracoastal Waterway]

\begin{tabular}{|c|c|c|c|c|c|c|c|c|c|c|c|c|c|c|c|}
\hline & \multicolumn{5}{|c|}{ Average 2003-8 } & \multicolumn{5}{|c|}{ Low water (2006) } & \multicolumn{5}{|c|}{ Peak flood (2008) } \\
\hline & $\begin{array}{c}\text { GIWW at } \\
\text { Bayou } \\
\text { Sale } \\
\text { Ridge } \\
\text { near } \\
\text { Franklin }\end{array}$ & $\begin{array}{c}\text { GIWW } \\
\text { at } \\
\text { Houma }\end{array}$ & $\begin{array}{c}\text { GIWW } \\
\text { west of } \\
\text { Bayou } \\
\text { Lafourche } \\
\text { at } \\
\text { Larose }\end{array}$ & $\begin{array}{c}\text { Davis } \\
\text { Pond } \\
\text { Freshwater } \\
\text { Diversion } \\
\text { near } \\
\text { Boutte }\end{array}$ & $\begin{array}{c}\text { Caernarvon } \\
\text { Outfall } \\
\text { Channel } \\
\text { at } \\
\text { Caernarvon }\end{array}$ & $\begin{array}{c}\text { GIWW at } \\
\text { Bayou } \\
\text { Sale } \\
\text { Ridge } \\
\text { near } \\
\text { Franklin }\end{array}$ & $\begin{array}{c}\text { GIWW } \\
\text { at } \\
\text { Houma }\end{array}$ & $\begin{array}{c}\text { GIWW } \\
\text { west of } \\
\text { Bayou } \\
\text { Lafourche } \\
\text { at } \\
\text { Larose }\end{array}$ & $\begin{array}{c}\text { Davis } \\
\text { Pond } \\
\text { Freshwater } \\
\text { Diversion } \\
\text { near } \\
\text { Boutte }\end{array}$ & $\begin{array}{c}\text { Caernarvon } \\
\text { Outfall } \\
\text { Channel } \\
\text { at } \\
\text { Caernarvon }\end{array}$ & $\begin{array}{c}\text { GIWW at } \\
\text { Bayou } \\
\text { Sale } \\
\text { Ridge } \\
\text { near } \\
\text { Franklin }\end{array}$ & $\begin{array}{c}\text { GIWW } \\
\text { at } \\
\text { Houma }\end{array}$ & $\begin{array}{c}\text { GIWW } \\
\text { west of } \\
\text { Bayou } \\
\text { Lafourche } \\
\text { at } \\
\text { Larose }\end{array}$ & $\begin{array}{c}\text { Davis } \\
\text { Pond } \\
\text { Freshwater } \\
\text { Diversion } \\
\text { near } \\
\text { Boutte }\end{array}$ & $\begin{array}{c}\text { Caernarvon } \\
\text { Outfall } \\
\text { Channel } \\
\text { at } \\
\text { Caernarvon }\end{array}$ \\
\hline Jan. & 9,370 & 1,770 & 1,970 & 1,700 & 3,510 & 5,080 & 1,210 & 1,070 & 1,730 & 2,670 & 8,550 & 507 & No data & 3,520 & 4,930 \\
\hline Feb. & 10,000 & 1,780 & 2,430 & 2,930 & 4,070 & 9,280 & No data & 1,410 & 3,630 & 3,100 & 9,940 & 1,040 & 1,890 & 7,580 & 6,360 \\
\hline Mar. & 11,000 & 2,180 & 1,690 & 2,090 & 4,650 & 7,400 & No data & 349 & 3,500 & 3,630 & 14,490 & 2,510 & 2,350 & 2,770 & 7,780 \\
\hline Apr. & 10,500 & 2,210 & 1,680 & 3,090 & 2,080 & 7,550 & No data & 662 & 3,990 & 3,380 & 18,900 & 3,400 & 2,300 & 6,280 & 2,480 \\
\hline May & 10,600 & 1,870 & 1,370 & 1,970 & 717 & 8,740 & No data & 1,090 & 2,910 & 1,610 & 18,000 & 4,470 & 3,030 & 4,140 & 937 \\
\hline June & 9,370 & 1,840 & 1,820 & 1,460 & 707 & 5,550 & 1,250 & 505 & 2,500 & 477 & 14,600 & 3,580 & 2,840 & 3,330 & 980 \\
\hline July & 8,110 & 1,600 & 1,800 & 1,990 & 614 & 3,400 & 838 & 563 & No data & 395 & 13,400 & 3,500 & 2,220 & 5,440 & 11 \\
\hline Aug. & 4,530 & 1,150 & 863 & 1,500 & 753 & 3,270 & 1,010 & 924 & No data & 834 & 8,000 & 2,880 & 634 & 2,770 & 823 \\
\hline Sept. & 4,330 & 427 & 97 & 1,150 & 738 & 3,520 & 1,020 & 846 & No data & 1,610 & 6,510 & -114 & $-1,550$ & 829 & 581 \\
\hline Oct. & 4,590 & 335 & 338 & 758 & 1,520 & 4,590 & 1,810 & 649 & 1,370 & 2,430 & 6,210 & 293 & 688 & 789 & 621 \\
\hline Nov. & 4,640 & 890 & 882 & 1,210 & 1,250 & 5,820 & 2,060 & 1,160 & 3,400 & 993 & 3,590 & No data & 437 & 1,200 & 616 \\
\hline Dec. & 6,300 & 1,180 & 1,270 & 1,720 & 2,450 & 5,710 & 895 & 1,480 & 3,350 & 2,770 & 3,950 & 932 & 410 & 2,000 & 1,340 \\
\hline Jan.-June ${ }^{1}$ & 10,140 & 1,940 & 1,830 & 2,200 & 2,620 & 7,270 & No data & 848 & 3,040 & 2,480 & 14,100 & 2,580 & 2,480 & 4,60 & 3,910 \\
\hline July-Dec. & 5,420 & 931 & 876 & 1,390 & 1,220 & 4,480 & 1,270 & 936 & 2,700 & 1,500 & 6,943 & 1,500 & 473 & 2,171 & 665 \\
\hline
\end{tabular}

${ }^{1}$ Six-month discharge averages. 


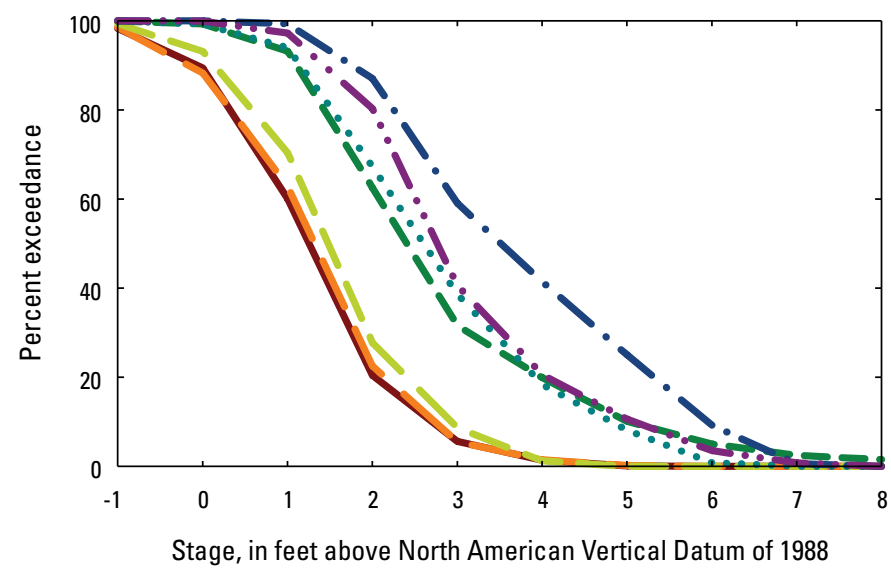

EXPLANATION

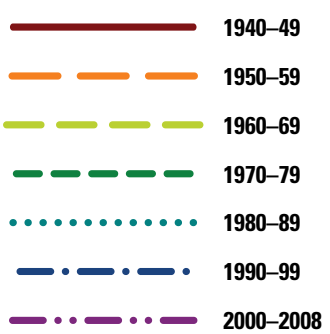

Figure 5. Percent time the Lower Atchafalaya River at Morgan City exceeded indicated stage. Stage was averaged in 10-year increments starting in January 1940 and extending through December 2008.

The exceedance curve of the 1990s was anomalous compared with all other decades. Rather than decreasing rapidly at stages greater than about $2-3 \mathrm{ft}$, the exceedance times decreased gradually. Reasons for the anomalous exceedance may be due to several years of high sustained flows during the decade; for example, as in 1993 when the LAR stage stayed above $3 \mathrm{ft}$ for much of the year (fig. 2). A weir across the WLO installed in 1988 was removed in 1994 and likely influenced patterns of discharge from the LAR and WLO into the GIWW as well.

The shift has increased the amount of time each year that the LAR at Morgan City (site 8) remains between 3 and $4 \mathrm{ft}$ or higher and, consequently, the annual discharge in the GIWW. If the long-term trend towards longer periods of higher stages of the LAR at Morgan City continues, the duration and amounts of flow in the GIWW could be expected to increase and with it the amount of river water reaching coastal Louisiana wetlands. The subaerial expansion of the deltas at the mouths of the LAR and WLO should slow down the travel times of the seasonal spring flood of the LAR and promote the lateral diversion of river water into the GIWW. Counter balancing this trend is the maintenance dredging in the LAR which reduces the infilling of the riverbed over time and increases the cross-channel volume at the mouth.
Discharge in relation to stage of the WLO at Calumet changed in the GIWW west of Jaws Bay near Cypremort between 1997 and 1998 and 2007 and 2008 (fig. 6). During the period 2007-8, there was little westward flow past Jaws Bay, in contrast to the earlier period. More recent measurements are needed to determine whether this change is permanent. At all other sites, discharge measured during the two periods did not show clear differences.

\section{Suspended Sediment}

Suspended-sediment concentrations west of the LAR were generally higher than concentrations east of the LAR. West of the LAR, median suspended-sediment concentrations were about $160 \mathrm{mg} / \mathrm{L}$ at all stations except for the Charenton Drainage Canal at Baldwin (site 1), which had lower concentrations (fig. 7). Values outside the 90th percentile were between 400 and $500 \mathrm{mg} / \mathrm{L}$. To the east, median concentrations at the Avoca Island Cutoff and Bayou Penchant south of Morgan City (sites 9 and 10, respectively) ranged between 120 and $140 \mathrm{mg} / \mathrm{L}$, higher than GIWW near Bay Wallace east of Morgan City (site 12) and GIWW west of HNC at Houma (site 13), where the median concentrations were about $100 \mathrm{mg} / \mathrm{L}$ and similar to median concentrations at Bayou Boeuf at the Railroad Bridge at Amelia (site 11) (fig. 7). The lower suspended-sediment concentrations along this stretch of the GIWW support the findings using discharge measurements that water from the Verret subbasin exits through Bayou Boeuf and mixes with LAR water coming from the Avoca Island Cutoff, diluting concentrations. Farther east, median suspended-sediment concentrations in the GIWW increased to about $120 \mathrm{mg} / \mathrm{L}$ at Houma (site 14) and to about $160 \mathrm{mg} / \mathrm{L}$ west of Bayou Lafourche at Larose (site 15). Suspended sediments are added to the water column along this stretch of the GIWW from local sources or through continual resuspension. Values outside the 90th percentile only reached between 260 and $340 \mathrm{mg} / \mathrm{L}$.

Compared to the GIWW between Bayou Boeuf and the HNC, the higher discharge in the GIWW between the LAR and Jaws Bay, combined with the 25-percent higher average suspended-sediment concentrations, make this stretch potentially more useful for delivery of suspended sediments for wetland restoration. The large drop in discharge in the GIWW across Jaws Bay also makes this shallow bay a potential area for suspended-sediment delivery and marsh creation.

\section{Salinity}

The variability of freshwater inflow to the Louisiana coast from the Mississippi and Atchafalaya Rivers, depending on the stage hydrographs of a particular water year, caused large year-to-year fluctuations in local estuarine salinity regimes in many parts of south-central coastal Louisiana. The fluctuations were caused indirectly by transport of river water into basin interiors and directly by freshwater inflow from the 


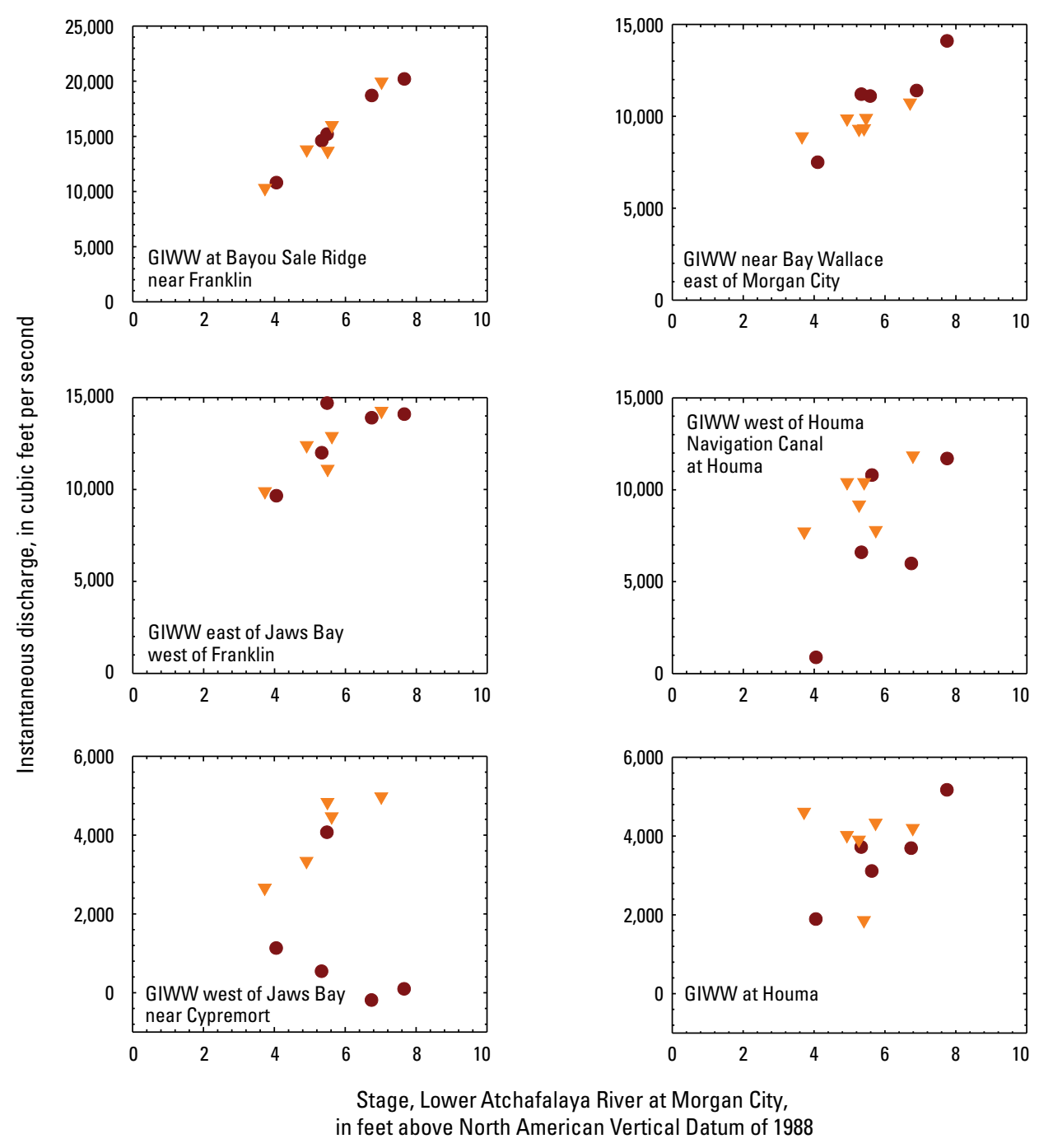

Figure 6. Comparison of instantaneous discharge measurements made in 1997 and 1998 and measurements made in 2007 and 2008 in relation to stage of the Lower Atchafalaya River at Morgan City.

GIWW. The salinity fluctuations in the basins demonstrate that river water can penetrate large parts of coastal Louisiana. The GIWW plays an important role in moderating salinity in intradistributary basins.

River discharge heavily influences salinity in the Vermilion-Teche Basin from January through June (fig. 8). At TV04-04R (fig. 1, site 20), closer to the source of river water, salinity was similar and less than 1 part per thousand (ppt) during the early part of the year even for low and average flow years. Salinity at TV04-04R (site 20) was higher in the late summer and fall months (August-November) during the low water year compared with average conditions. Farther west at Vermilion Bay (fig. 1, site 19), a similar trend was observed, but average salinity was higher than that at TV04-04R (site 20) throughout the year (fig. 8). Sustained high water and peak flood conditions decreased salinity below long-term averages for most of the year, including in the spring and early summer, to levels that were similar to those at TV04-04R (site 20). During the low water year, the reduced volumes of river water allowed salinity to increase over average conditions by $2-5$ ppt from January through June and then by more than 10 ppt in late summer. Freshwater likely reached this area through westward drift of water towards Cypremort Point from the mouths of the LAR and WLO and from the GIWW through Jaws Bay (fig. 8).

Terrebonne Basin surface waters were sensitive to freshwater inflows through the GIWW. Salinity in the spring and summer months was similar and averaged below $1 \mathrm{ppt}$ during low water and peak flood conditions at TE28-07R (fig. 1, site 21) (fig. 8). Salinity during the low water year was not markedly higher than during average conditions, an indication that freshwater inflow from Bayou Boeuf continued to moderate salinity even under low river flow. Farther south at Caillou Lake (site 22), sustained high water suppressed salinity below average conditions for the entire year, at times by $7 \mathrm{ppt}$ or more. During the peak flood year, salinity was below long-term average conditions only from early summer through July. During the low water year (2000), salinity spiked 

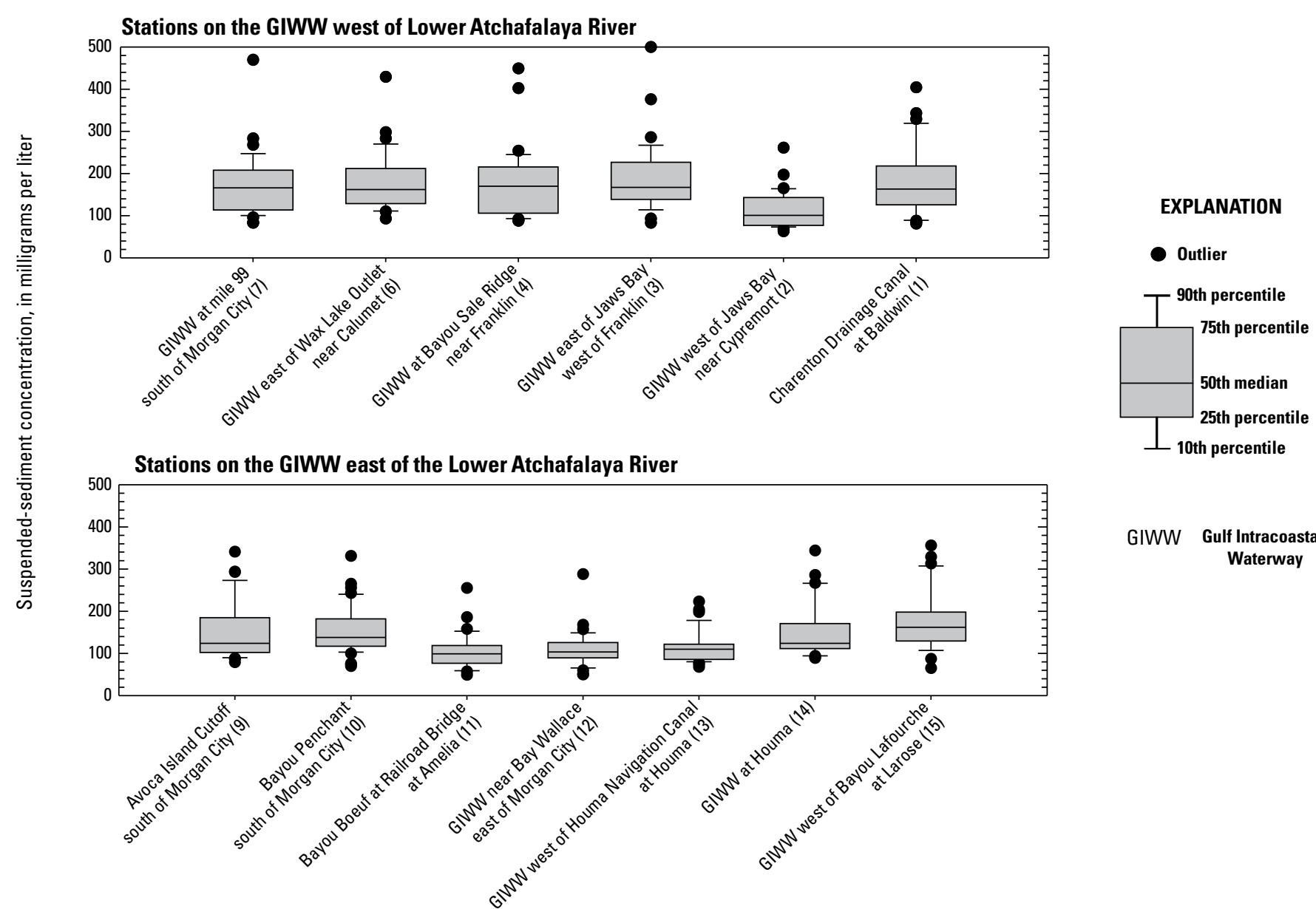

GIWW Gulf Intracoastal Waterway

Figure 7. Statistical summary of suspended-sediment concentrations collected between 1997 and 2008 at selected locations in the Gulf Intracoastal Waterway (GIWW) and adjacent surface-water bodies. Site numbers in parentheses.

in May and June and again during October and November, with values as much as 7 ppt higher than average conditions (fig. 8). The spikes mimic the average water conditions in timing but were extreme in magnitude because of the regional drought occurring in south-central Louisiana at the time. The majority of the freshwater controlling salinity at both of these areas most likely came from the GIWW, rather than from Mississippi River water drifting westwards in the Gulf of Mexico. At Caillou Bay (fig. 1, site 23), salinity during peak flood conditions only decreased to about $15 \mathrm{ppt}$ (fig. 8). During the low water year (2000), salinity remained between 25 and 30 ppt, about 4-5 ppt higher than salinity during average conditions.

Not surprisingly, surface waters in Barataria Basin, the basin farthest from Morgan City in this study, were the least affected by freshwater inputs from the GIWW. In Barataria Basin, the site at Lake Salvador (fig. 1, site 24), the farthest inland site, was sensitive to the lack of freshwater inflow in 2000, when the Davis Pond Freshwater Diversion Structure was not yet operational (fig. 8). Average monthly salinity increased by 2-6 ppt throughout 2000 compared with average conditions. The lack of local rainfall coupled with low river discharge may have allowed salinity to become elevated. During the peak flood year, salinity dropped below average conditions, to values similar to other inland sites, for example in the Teche-Vermilion basin (TE28-07R, site 21) and in Terrebonne Basin (TV04-04R, site 20). Freshwater entering the area from the Davis Pond Freshwater Diversion Structure contributed to the low salinity values during the peak flood year. Salinity concentrations at Little Lake (fig. 1, site 25) were below long-term averages for both the year with sustained high water and the peak flood year and were between less than 5 and 16 ppt lower than during the low water year (fig. 8). Salinity values spiked dramatically during May and June 2000, similar to Caillou Lake (site 22), and were much higher than those for long-term average conditions. During years when river discharge is high, this area receives water from the GIWW through Bayou Perot (Swarzenski, 2003) from local runoff and also from Mississippi River water drifting westwards from the mouth and then in an inland direction. Farther south, in Barataria Bay north of Grand Isle (site 26), salinity during the low water year remained between 20 and 25 ppt, higher than the long-term average and substantially higher than salinity during 1993 and spring and early summer in 2008 (fig. 8). At 
VERMILION-TECHE BASIN
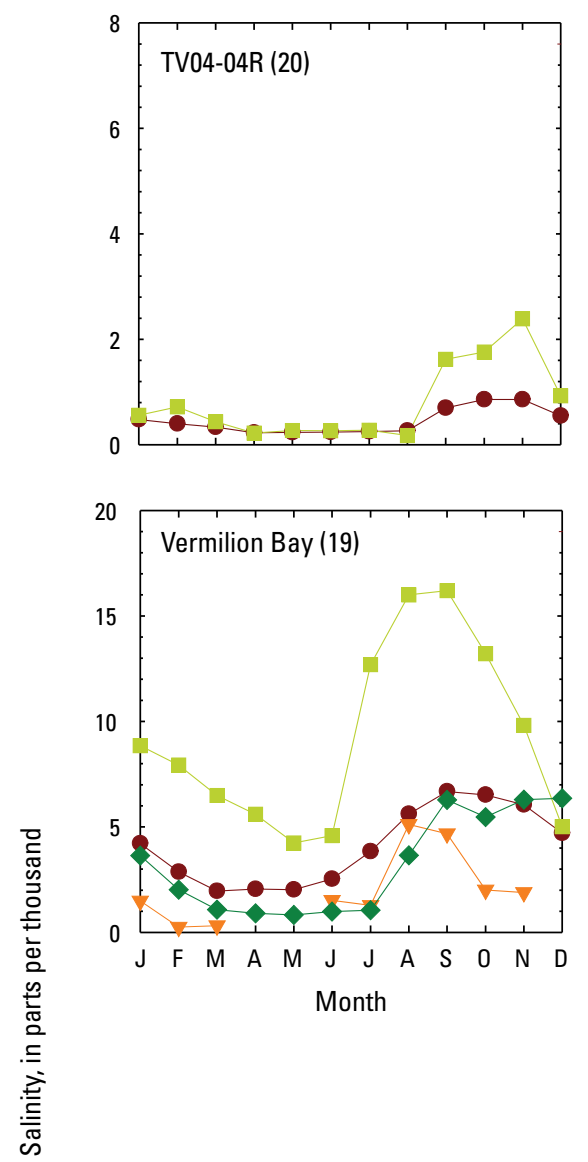

EXPLANATION

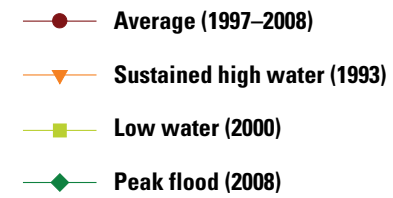

TERREBONNE BASIN
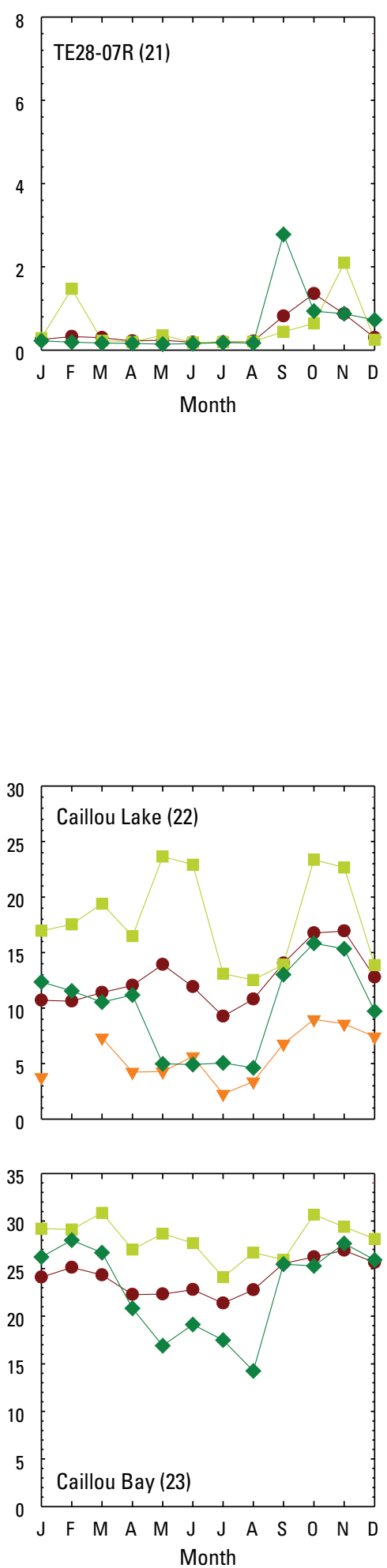

BARATARIA BASIN
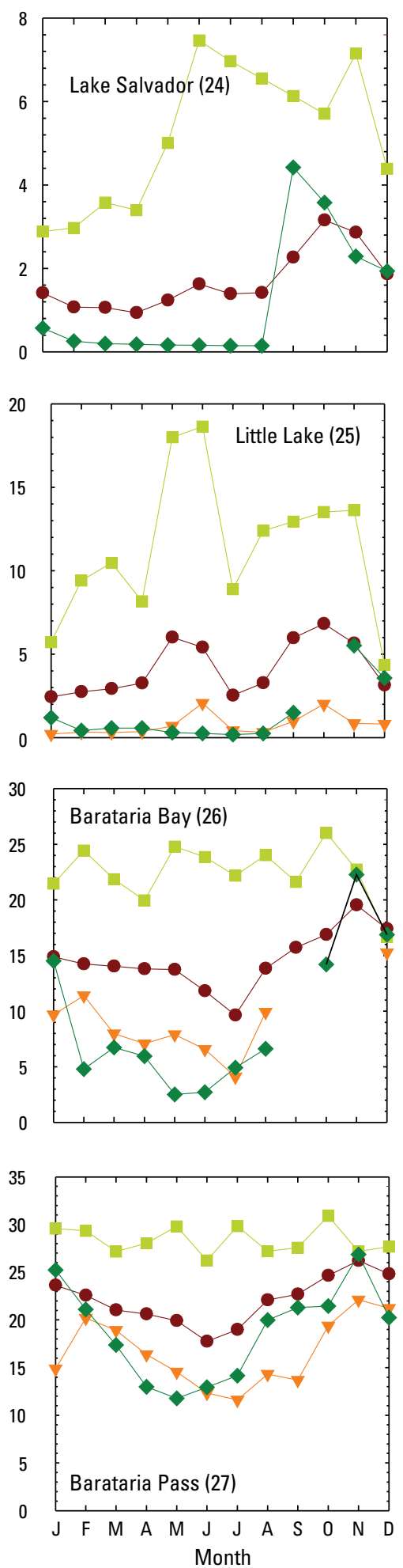

Figure 8. Monthly average salinity at selected stations in south-central Louisiana under average, sustained high water, low water, and peak flood conditions of the Atchafalaya River. Not all stations were operational in 1993; months with more than 50 percent missing data are not shown. 
the boundary between Barataria Basin and the Gulf of Mexico, at Barataria Pass (fig. 1, site 27), salinity remained around 30 ppt throughout the low water year 2000, 5 ppt or more above the long-term average for all months except for November and December. During sustained high water and peak flood years, salinity decreased below long-term averages. Salinity in the fall was higher during 2008 than during the year with sustained high water (fig. 8).

Barataria Basin was the only intradistributary basin in which salinity became substantially elevated in the upper reaches during the low water year (2000) (fig. 9). This occurred before the Davis Pond Freshwater Diversion Structure was operational. The capability of introducing river water into Barataria Basin through the Davis Pond Freshwater Diversion Structure, which commenced operations in 2004, has reduced the vulnerability of the low-salinity marshes here to elevated salinity during low water years. In 2006, a year comparable to 2000 with similar low water conditions and precipitation for much of the year (table 2), the Davis Pond Freshwater Diversion Structure was operating, and the influence of this added source of freshwater in moderating salinity was readily apparent. The diversion inflow in 2006 substantially lowered ambient salinity in the upper reaches near Lake Salvador compared with 2000 when the diversion was not yet operational (fig. 9).

\section{Implications for Coastal Louisiana}

The salinity gradient dominates the biology and ecology of estuaries, which are typically highly productive environments (Odum, 1988). Differential salt tolerance arranges plant communities and controls the occurrence and distribution of organisms, including fish, at all levels (Telesh and Khlebovich, 2010; Whitfield and others, 2012). Biogeochemical processing of detrital material and the structure and dynamics of food webs also are controlled by the salinity gradient (Odum, 1988). By moving marine saltwater and fresh river water around basins in artificial ways, the GIWW influences natural processes, potentially displaces organisms, and adds yet more complexity to an already fragile and complicated system.

The altered hydrology enables the GIWW to introduce fresh river water to parts of the Mississippi River Delta that cannot be reached any other way. Freshwater moderates salinity; this has intrinsic value in low-salinity reaches of estuaries, provided that the water can be delivered when it is most needed, for example during drought conditions or during the fall when salinity tends to peak in coastal waters. River water also is highly valued for potential nourishment and restoration of degraded marshes (Nyman, 2014). Some projects have been implemented and additional ones are being proposed to take advantage of the discharge in the GIWW; the apparent nourishing property of river water underlies the use of controlled river diversions off the Mississippi River in the Coastal Master Plan for restoration of the delta wetlands (Coastal Protection and Restoration Authority, 2015).
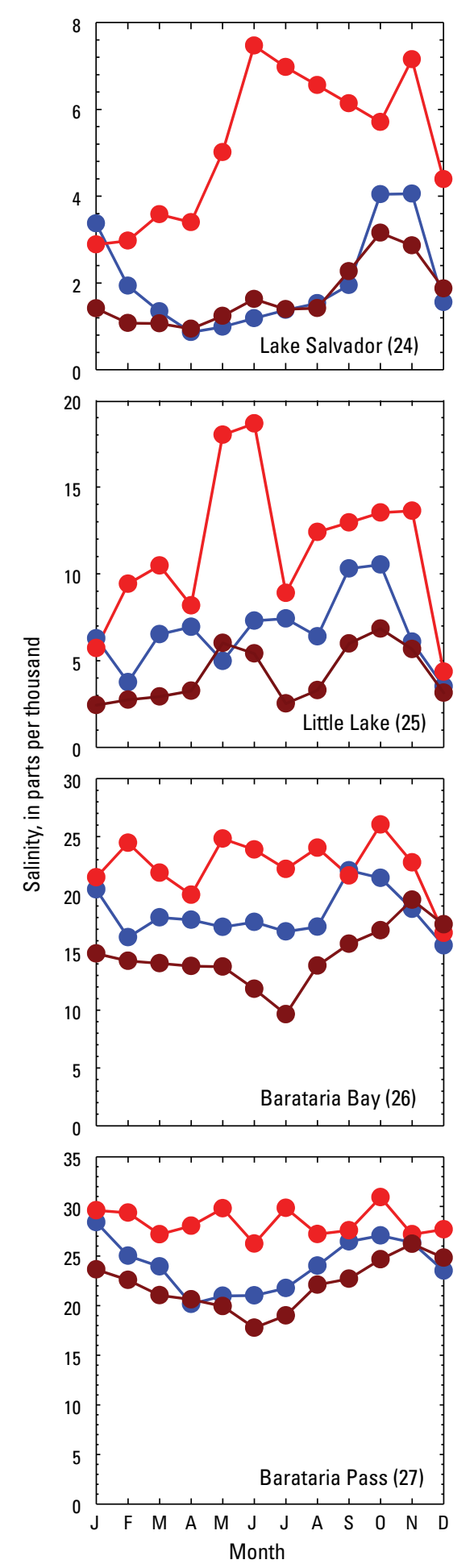

\section{EXPLANATION}

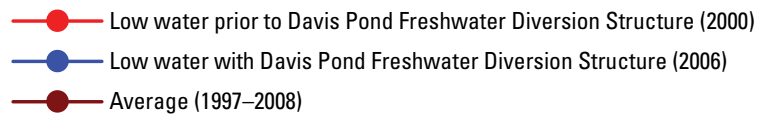

Figure 9. Monthly average salinity in parts per thousand at selected stations in Barataria Basin under average and low water conditions of the Atchafalaya River. The Davis Pond Freshwater Diversion Structure was not operational in 2000. 
The introduction of river water into marshes is not without controversy, however, and the processes by which river water is assumed to benefit marshes are not well understood (Turner, 2009). Since the early 1950s, the Mississippi River carries high nutrient and herbicide loads from midcontinent agricultural runoff during the spring flood (Turner and Rabalais, 2003). Recent research has shown that coastal eutrophication and chronic exposure to elevated nitrogen may contribute to degradation of salt and fresh marsh soils (Swarzenski and others, 2008; Turner, 2011; Deegan and others, 2012; Valiela, 2015). These studies contrast with other efforts, many of which are summarized in Morris and others (2013) and suggest that nutrients are not harmful to marshes. The issue is difficult to research in controlled experimental settings because both beneficial and adverse marsh responses might take years to manifest themselves. In this instance too, the river water moving in the GIWW can serve a valuable purpose. The GIWW has been discharging river water into wetlands for decades and provides a quasi-natural setting in which to evaluate wetland responses to long-term influx of nutrient-rich waters (Swarzenski and others, 2008). The newly built diversions have only been operating for short periods, and outcomes may not be understood for many years. Careful study of the surface-water hydrology of the GIWW and the nearby marshes receiving long-term inflow of this river water could yield helpful clues about the use of river water and controlled diversions for coastal restoration not attainable through other ways.

Understanding flows in the GIWW and knowing when the GIWW acts as a source of water to surrounding surface waters and wetlands or as a sink receiving water from adjacent wetlands help in assessing estuarine structure and function. This understanding also is important to guide wetland restoration activities. Computed discharge data at both ends of discrete segments of the GIWW are needed to achieve this type of understanding. How this might work is illustrated for the segment between the HNC and Bayou Lafourche, the only segment along the GIWW that has gages continuously computing discharge at both ends. In March, April, and May, about $500 \mathrm{ft}^{3} / \mathrm{s}$ discharged from the GIWW into the surrounding wetlands under longterm average conditions (table 7). During the peak flood year, this amount exceeded 1,100 ft $3 / \mathrm{s}$ both in April and in May. Under long-term average conditions in January and February, water flowed from the surrounding wetlands into the GIWW along this segment (table 7). It was this inflow that maintained the prevailing eastward hydraulic gradient.

Similar analyses are possible elsewhere along the GIWW if additional gages measuring continuous velocity and stage are installed at the beginning and ends of discrete segments. Such information is required to make optimal use of freshwater flowing in the GIWW for wetland restoration projects.

\section{Summary}

Analysis of over 10 years of synoptic and continuous discharge measurements showed that the Gulf Intracoastal Waterway (GIWW) distributes river water and suspended sediments to intradistributary basins and associated coastal wetlands in south-central Louisiana at least 30 and 50 miles west and east, respectively, of Morgan City. The flow is passive and follows natural hydraulic gradients between water levels of the source waters, the Lower Atchafalaya River (LAR) and Wax Lake Outlet (WLO), and water levels in the GIWW and surrounding surface waters. The magnitude of the discharge in the GIWW increased as stages of the LAR and WLO increased. Discharge decreased with increasing distance from the LAR and WLO. In general, discharge increases steadily as stage of source waters increases; discharge at many locations in the GIWW becomes predictable when stage of the LAR at Morgan City (site 8) is between 3 and 4 feet ( $\mathrm{ft}$ ) referenced to the North American Vertical Datum of 1988 or higher. For some parts of coastal Louisiana too far away from the Mississippi River, the GIWW is the only means of getting river water to adjacent surface waters.

When stage of the LAR at Morgan City (site 8) was above $5.5 \mathrm{ft}$, an average of 31,500 cubic feet per second $\left(\mathrm{ft}^{3} / \mathrm{s}\right)$ entered the GIWW at mile 99 south of Morgan City (site 7). Of this inflow, on average $11,400 \mathrm{ft}^{3} / \mathrm{s}$ reached the WLO; the balance flowed south towards the Gulf of Mexico. At the same stage, discharge averaged about $18,000 \mathrm{ft}^{3} / \mathrm{s}$ in the GIWW at the Bayou Sale Ridge near Franklin (site 4) and 14,500 ft $\mathrm{ft}^{3} / \mathrm{s}$ in the GIWW east of Jaws Bay west of Franklin (site 3). Much of this water exited into Jaws Bay, a shallow bay. Only about 4,000 ft $3 / \mathrm{s}$ continued west in the GIWW west of Jaws Bay near Cypremort (site 2) when stage of the LAR at Morgan City (site 8) was above $5.5 \mathrm{ft}$. East of Morgan City, discharge averaged 23,000 ft $3 / \mathrm{s}$ at the Avoca Island Cutoff south of Morgan City (site 9) when stage of the LAR at Morgan City (site 8) was greater than $5.5 \mathrm{ft}$. Under these conditions, about $10,000 \mathrm{ft}^{3} / \mathrm{s}$ of water flowed in the GIWW west of Houma Navigation Canal (HNC) at Houma (site 13), and only about $3,600 \mathrm{ft}^{3} / \mathrm{s}$ continued in the GIWW towards Bayou Lafourche. When the LAR stage was high, the HNC captured substantial amounts of water flowing east in the GIWW. On average, about 2,700 $\mathrm{ft}^{3} / \mathrm{s}$ flowed east in the GIWW east of Bayou Lafourche at Larose (site 16) and into Barataria Basin when stage of the LAR at Morgan City exceeded $4 \mathrm{ft}$. When stage of the LAR at Morgan City (site 8) was below $3 \mathrm{ft}$, on average more than one-third of the discharge in the GIWW near Bay Wallace east of Morgan City (site 12) came from Bayou Boeuf. During years when LAR flow was low, Bayou Boeuf, draining the Verret subbasin, became a major source of water maintaining eastward flow in the GIWW.

The amount of river water flowing along the GIWW was shown to vary considerably from year to year depending on the hydrograph of the LAR. The annual discharge of water in the GIWW was greatest during a year with sustained 
high water (1993). The above average discharge during the second half of the year, when stage of the LAR at Morgan City (site 8) remained anomalously high, provided the main difference, but from January to June overall flow was greater in 1993 than flow during the peak flood of 2008; for example, the average discharge at the GIWW at Bayou Sale Ridge near Franklin (site 4) from January to June 1993 was 15,500 ft³/s, about 2,000 ft $3 / \mathrm{s}$ more than for the peak flood year of 2008 and over 10,000 ft $3 / \mathrm{s}$ more than during the drought year of 2006 for the same time interval. For the second half of 1993, the average discharge at this same site was $12,100 \mathrm{ft}^{3} / \mathrm{s}$, compared with about 7,000 ft $3 / \mathrm{s}$ in 2008 and 4,000 ft $\mathrm{ft}^{3} / \mathrm{s}$ for the same time period in 2006. Conversely, discharge in the GIWW was noticeably below average for the first 6 months of a year when flow of the LAR remained low for most of the year, as occurred in 2006, but was not that different during the second half of the year.

The length of time stage of the LAR at Morgan City (site 8) exceeding a given elevation increased from the 1940s to 2008, most dramatically during the 1970s. This shift increases the amount of time the GIWW functions as a predictable distributary of river water. Similar shifts in the future could be expected to increase the duration and amounts of river water reaching coastal Louisiana wetlands through the GIWW.

Median suspended-sediment concentrations in the GIWW to the west of Morgan City were about 160 milligrams per liter (mg/L). In the GIWW east of Morgan City, median concentrations were 120-160 mg/L, except in Bayou Boeuf at Railroad Bridge in Amelia and the parts of the GIWW between Bayou Boeuf and the HNC; median concentrations here were around $100 \mathrm{mg} / \mathrm{L}$. Compared to the GIWW between Bayou Boeuf and the HNC, the higher discharge in the GIWW between the LAR and Jaws Bay, combined with the 25-percent higher average suspended-sediment concentrations, make this stretch potentially more useful for delivery of suspended sediments for wetland restoration.

The variability of freshwater inflow to the Louisiana coast from the Mississippi and Atchafalaya Rivers caused large year-to-year fluctuations in local estuarine salinity regimes in many parts of south-central coastal Louisiana. These fluctuations demonstrate that river water penetrates much of the Louisiana coast. The contributing role of freshwater inflow through the GIWW and controlled river diversions was evident in the intradistributary basins west and east of Morgan City; for example, salinity in surface waters just south of the GIWW between Bayou Boeuf and the HNC remained low even during a year with prolonged low water (2000). This was not the case farther east in Barataria Basin, where only controlled inflow from the Davis Pond Freshwater Diversion Structure could moderate salinity in the upper reaches of the basin during a low water year. The GIWW plays an important role in moderating salinity in intradistributary basins.

\section{References Cited}

Coastal Protection and Restoration Authority, 2014, Miscellaneous hydrologic data: Accessed December 20, 2014, at http://cims.coastal.la.gov/DataDownload/ DataDownload.aspx?type=hydro_hourly.

Coastal Protection and Restoration Authority, 2015, 2012 Coastal master plan: Accessed January 20, 2015, at http://coastal.la.gov/a-common-vision/2012-coastal-masterplan/.

Deegan, L.A., Johnson, D.S., Warren, R.S., Peterson, B.J., Fleeger, J.W., Fagherazzi, Sergio, and Wollheim, W.M., 2012, Coastal eutrophication as a driver of salt marsh loss: Nature, v. 490, p. 388-392.

Edwards, T.K., and Glysson, G.D., 1999, Field methods for measurement of fluvial sediment: U.S. Geological Survey Techniques of Water-Resources Investigations, book 3, chap. C2, 89 p.

Morlock, S.E., Nguyen, N.T., and Ross, J.H., 2001, Feasibility of acoustic Doppler velocity meters for the production of discharge records from U.S. Geological Survey streamflowgaging stations: U.S. Geological Survey Water-Resources Investigations Report 01-4157, 56 p.

Morris, J.T., Shaffer, G.P., and Nyamn, J.A., 2013, Brinson review-Perspectives on the influence of nutrients on the sustainability of coastal wetlands: Wetlands, v. 33, p. 975-988.

National Oceanic and Atmospheric Administration, National Climatic Data Center, 2009, Climate data online: Accessed January 12, 2009, at http://www7.ncdc.noaa.gov/CDO/ CDODivisionalSelect.jsp.

Nyman, R.A., 2014, Integrating successional ecology and the delta lobe cycle in wetland research and restoration: Estuarines and Coasts, v. 37, p. 1490-1505.

Odum, W.E., 1988, Comparative ecology of tidal freshwater and salt marshes: Annual Review of Ecology and Systematics, v. 19, p. 147-176.

Paille, Ronald, 1997, Lower Atchafalaya Basin Reevaluation Study-Planning aid report on freshwater inflows to the Terrebonne Basin—Report submitted to the New Orleans District, U.S. Army Corps of Engineers: Lafayette, Louisiana, U.S. Fish and Wildlife Service, Ecological Services, $28 \mathrm{p}$.

Simpson, M.R., and Oltmann, R.N., 1993, Dischargemeasurement system using an Acoustic Doppler Current Profiler with applications to large rivers and estuaries: U.S. Geological Survey Water-Supply Paper 2395, 32 p. 
Swarzenski, C.M., 2003, Surface-water hydrology of the Gulf Intracoastal Waterway in south-central Louisiana, 1996-99: U.S. Geological Survey Professional Paper 1672, 51 p.

Swarzenski, C.M., Doyle, T.W., Fry, Brian, and Hargis, T.G., 2008, Biogeochemical response of organic-rich freshwater marshes in the Louisiana delta plain to chronic river water influx: Biogeochemistry, v. 90, p. 49-63.

Telesh, I.V., and Khlebovich, V.V., 2010, Principal processes within the estuarine salinity gradient-A review: Marine Pollution Bulletin 61, p. 149-155.

Turner, R.E., 2009, Doubt and the values of an ignorancebased world view for restoration-Coastal Louisiana wetlands: Estuaries and Coasts, v. 32, p. 1054-1068.

Turner, R.E., 2011, Beneath the salt marsh canopy-Loss of soil strength with increasing nutrient loads: Estuaries and Coasts, v. 34, p. 1084-1093.

Turner, R.E., and Rabalais, N.N., 2003, Linking landscape and water quality in the Mississippi River Basin for 200 years: BioScience, v. 53, p. 563-572.
U.S. Army Corps of Engineers, 2009, Stage data for the Atchafalaya River at Simmesport and for the Lower Atchafalaya River at Morgan City, 1940-2008: Accessed January 12, 2009, at http://rivergages.mvr.usace.army.mil/ WaterControl/search2.cfm.

Valiela, V., 2015, The Great Sippewissett salt marsh plotsSome history, highlights, and contrails from a long-term study: Estuaries and Coasts, v. 38, p. 1099-1120.

Wells, F.C., and Demas, C.R., 1977, Hydrology and water quality of the Atchafalaya River Basin: Louisiana Department of Transportation and Development, Office of Public Works Water Resources Technical Report no. 14, $53 \mathrm{p}$.

Whitfield, A.K., Elliot, M., Basset, A., Blaber, S.J.M., and West, R.J., 2012, Paradigms in estuarine ecology-A review of the Remane diagram with a suggested revised model for estuaries: Estuarine, Coastal and Shelf Science, v. 97, p. 78-90. 


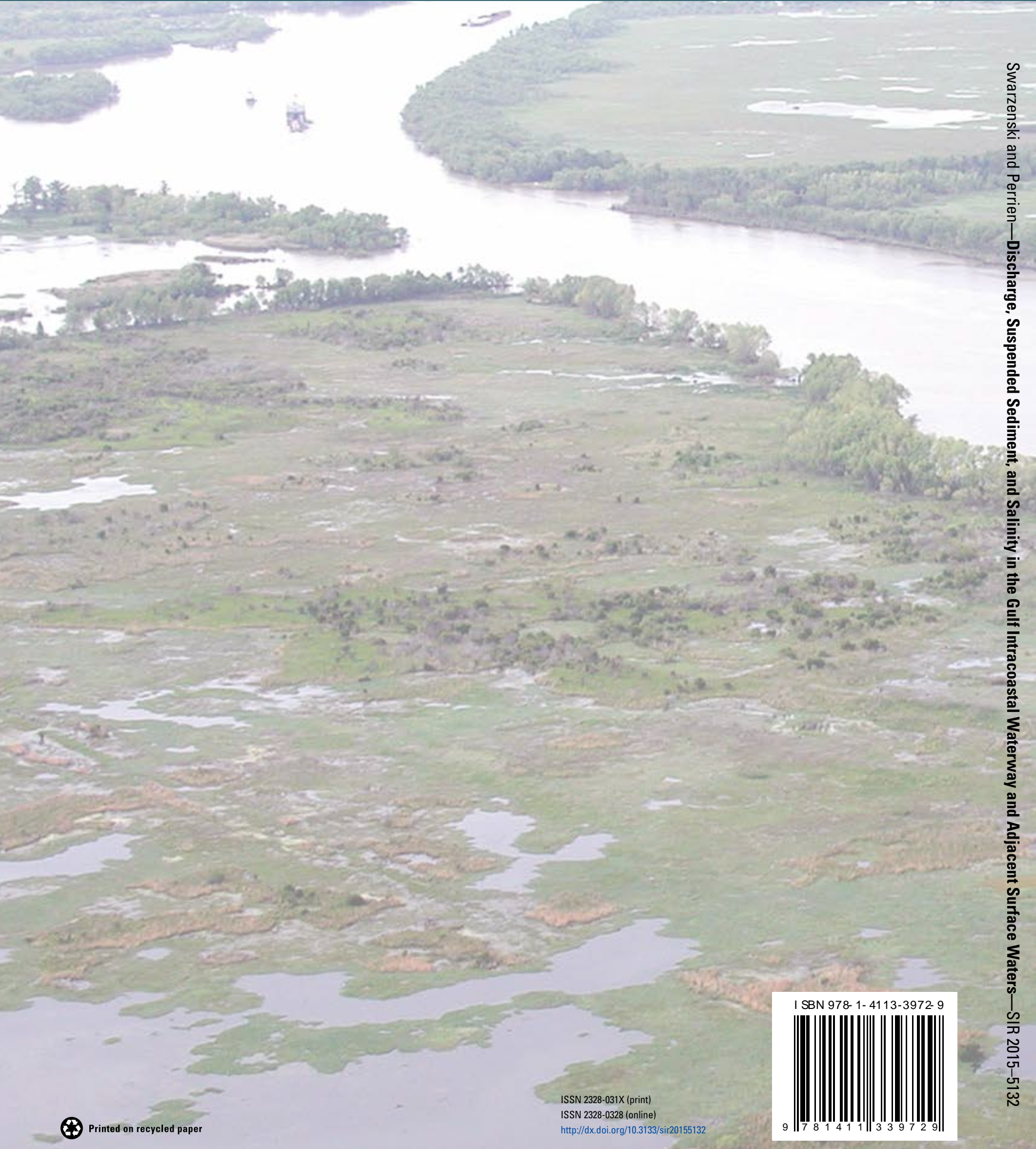

